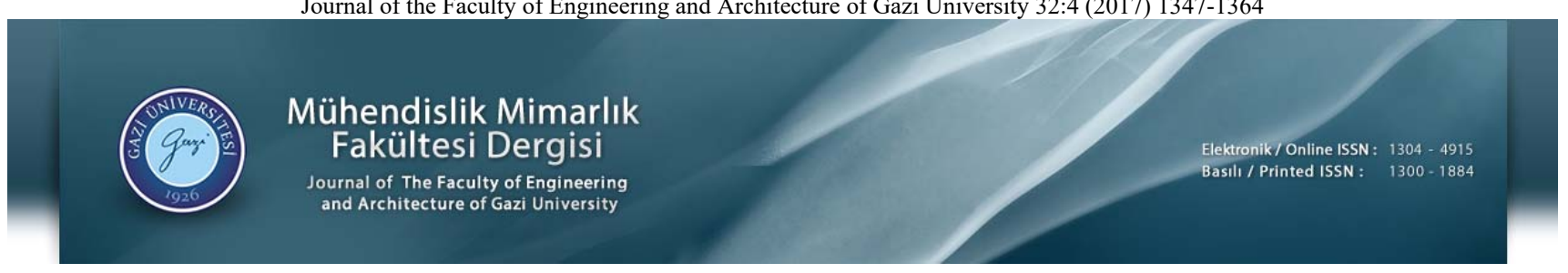

\title{
Erken yaş büzülme çatlaklarının lif içeren/içermeyen ultra yüksek performanslı betona gömülü donatı korozyonuna etkisi
}

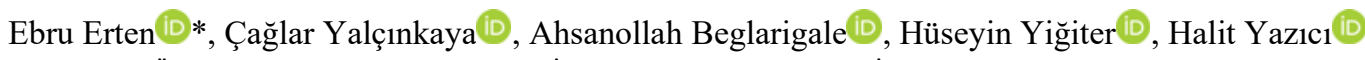

Dokuz Eylül Üniversitesi, Mühendislik Fakültesi, İnşaat Mühendisliği Bölümü, İzmir, 35160, Türkiye

\section{Ö N E Ç I K A N L A R}

- Mineral katkılı ultra yüksek performanslı beton

- Erken yaşta bünyesel büzülme ve kuruma büzülmesi davranışı

- Büzülme çatlaklarının ve mineral katkıların donatı korozyonuna etkisi

Makale Bilgileri

Geliş: 04.09.2016

Kabul: 15.12 .2016

DOI:

10.17341/gazimmfd.369857

Anahtar Kelimeler:

Ultra yüksek performanslı

beton,

donatı çeliği,

kalıcilık,

klorid korozyonu,

korozyon akım yoğunluğu

\section{ÖZET}

Bu çalışmada, iki farklı başlangıç ortamında bekletilmiş lif içeren ve içermeyen ultra yüksek performanslı beton (UYPB) karışımlarının erken yaş (ilk 24 saat) büzülme özellikleri incelenmiştir. Erken yaşta oldukça yüksek mertebelerde büzülme gösteren karışımların kısıtlanmış halde bekletilmesi halinde oluşan çatlakların çelik donatının korozyon gelişimine etkisi deneysel olarak belirlenmiştir. Kısıtlanmış büzülme çatlaklarının çelik donatı korozyonu üzerinde bazı olumsuz etkiler yarattığı tespit edilmiştir. Ancak düşük su/bağlayıcı oranlı UYPB örneklerinin yüzeyinde çatlak oluşmasına rağmen, donatıyı korumada oldukça iyi performans gösterdiği görülmüştür. UYPB'nin en önemli özelliği, geçirimsiz yapısı nedeniyle sağladığı üstün durabilite (kalıcılık) özelliğidir. UYPB'nin kalıcılık özelliklerinin korunması için erken yaş çatlaklarının önlenmesi amacıyla gerekli önlemler alınmalıdır. Çalışma kapsamında yapılan analizler, uçucu kül ikamesinin ve mikro çelik lif takviyesinin çatlak oluşumunu azaltarak donatı korozyonuna karşı korumayı geliştirdiğini göstermiştir.

\section{Effect of early age shrinkage cracks on the corrosion of rebar embedded in ultra high performance concrete with and without fibers}

\section{H I G H L I G H T S}

- Ultra high performance concrete containing mineral admixtures

- Early age autogenous and drying shrinkage behavior

- Effect of shrinkage cracks and mineral admixtures on the corrosion of rebar

Article Info

Received: 04.09.2016

Accepted: 15.12 .2016

DOI:

10.17341/gazimmfd.369857

Keywords: Ultra high performance concrete, steel reinforcement, durability, chloride induced corrosion, corrosion current density

\section{ABSTRACT}

In this study, early age (first 24 hours) shrinkage properties of Ultra High Performance Concrete (UHPC) mixtures with and without fibers, exposed to two different initial curing conditions, were investigated. The effect of early age shrinkage cracks on development of corrosion of steel reinforcement embedded in UHPC has been determined experimentally. Some negative effects of restrained shrinkage cracks on corrosion of embedded steel reinforcement were determined. In spite of the cracks formation on the surface of UHPC specimens with low water to binder ratio, the UHPC mixtures showed generally good performance in terms of the protection of rebar against corrosion. Although cracks formed on surfaces of impermeable UHPC mixtures, which consist of low water to binder ratio, UHPC showed generally good performance on the protection of steel corrosion. The most important characteristic of UHPC is superior durability due to its impermeable nature. In order to maintain the durability properties of UHPC, necessary precautions should be taken to prevent early age cracks. The analysis conducted in this study revealed that fly ash replacement and micro steel fiber reinforcement enhanced protection against corrosion of rebars by means of reducing crack formation.

\footnotetext{
*Sorumlu Yazar/Corresponding Author: ebru_erten@outlook.com / Tel: +90 2323017042
} 


\section{GÍRIŞS (INTRODUCTION)}

Beton basınç dayanımındaki artış genel itibariyle servis koşulları altındaki betonarme elemanların kalıcılığını da arttırmaktadır. Dayanım ve dayanıklılık beraber gelişerek yüksek performans deyimini ortaya çıkarmıştır. Beton basınç dayanımına göre $40 \mathrm{MPa}$ ya kadar normal beton (NB), 40 ila $80 \mathrm{MPa}$ arası yüksek performanslı beton (YPB), 80 ila 150 $\mathrm{MPa}$ arası çok yüksek performanslı beton (ÇYPB) ve 150 MPa üzerine ultra yüksek performanslı beton (UYPB) isimlendirmeleri kullanılmaktadır [1]. Yüksek performanslı betonlarda düşük su/bağlayıcı oranı özellikle bünyesel büzülmeyi risk haline getirmektedir [2, 3]. Yüksek hidratasyon 1sısı ve kapiler su kaçışları bu etkiyi tetiklemektedir [4]. Kuruma büzülmesinin 0,30 su / bağlayıcı oranı altındaki betonlarda büyük bir risk yaratmayacağı gibi bir yargı literatüre bakıldı ğında ilk etapta dikkati çekebilir [5]. Ancak uygulanan kür rejiminin ve kullanılan katk1 maddelerin bu durumu tamamen değiştirebileceği görülmektedir [6]. Büzülme çatlaklarının yüksek performanslı çimentolu kompozitlerden beklenen durabiliteyi ve mekanik performansı azaltacağı söylenebilir. Büzülme çatlakları riskinin sadece sahada olmadı̆̆ 1 , kontrollü fabrikasyon üretimde 1sıl kürün başlatılmasına kadar geçen süreçte de gelişebildiği görülmektedir [7]. Büzülme çatlakları riskinin azaltılmasında malzeme tasarımı açısından birçok önlem tipi bulunmaktadır [8]. Bunlardan çeşitli puzolanların ikamesi sonucu olumlu/olumsuz sonuçlar elde edilebileceği görülmektedir $[9,10]$.

Betonarme yapılardan beklenen servis ömrünün sağlanabilmesi için çelik donatı korozyonuna karşı önlemler alınmaktadır. Bu önlemlerin başında ilgili çevresel etkilere uygun, geçirimsiz bir beton kullanımı ve yeterli miktarda pas payı uygulaması gelmektedir. Gerçekleştirilen çalışmalarda çimento hamurunun betonun elektriksel direncini kontrol eden temel faz olduğu, pas payı kalitesinin ve kalınlığının korozyon gelişimindeki hayati rolü gösterilmiştir $[11,12]$. Çeliklerin maruz kaldığı ortamda farklı mekanizmalar bir araya gelerek bozulma sürecini hızlandırabilmektedir [13, 14]. Zivica [15], karbonatlaşma ve klorür etkilerinin bir arada olduğunda donatı korozyonunun şiddetlendiğini göstermiştir. Karbonatlaşma ardından klorid saldırısının korozyonu şiddetlendirici etkisi, boşluk çözeltisinin alkalinitesinin azalmasının ve dolayısıyla donatının elektrokimyasal olarak depasivasyonunun bir sonucudur [16]. Literatürdeki araştırmalar büzülme çatlakları içermeyen geleneksel betonlar üzerine yoğunlaşmaktadır. Ancak geleneksel betona kıyasla oldukça geçirimsiz olan UYPB türü kompozitlerin sergilediği yüksek orandaki büzülme ve buna bağl1 çatlaklar, hesapta olmayan korozyon sorunlarına neden olabilir.

Bu çalışmada lif takviyeli ve takviyesiz UYPB'de kısıtlanmış halde gelişen erken yaş büzülme çatlaklarının donatı korozyonuna etkisi araştırılmıştır. Ayrıca yüksek oranda uçucu kül (UK) ve öğütülmüş yüksek firın cürufu (YFC) ikamesinin serbest büzülme davranışına, büzülme çatlakları oluşumuna ve buna bağlı korozyon gelişimine etkisi incelenmiştir.

\section{MALZEME VE YÖNTEM (MATERIAL AND METHOD)}

\subsection{Malzemelerin Özellikleri ve Karıșım Oranları (Properties of Materials and Mix Designs)}

Deneylerde kullanılan CEM I 42,5 R çimentosu, silis dumanı (SD), YFC ve UK'nın fiziksel ve kimyasal özellikleri Tablo 1 ve 2 'de verilmiştir. Agrega olarak dört boyut aralığında kuvars agregası kullanılmıştır; $0-0,4 \mathrm{~mm}, 0,5-1 \mathrm{~mm}, 1-$ $3 \mathrm{~mm}$ ve $5-8 \mathrm{~mm}$. Kullanılan mikro çelik lifler $6 \mathrm{~mm}$ uzunluğa, 0,16 mm çapa sahip pirinç kaplı liflerdir. Hiperakışkanlaştırıcı olarak BASF firmasının geliştirdiği Glenium ACE 30 kullanılmıştır. Tempcore yöntemi ile nervürlü olarak imal edilen donatıların anma çapı $10 \mathrm{~mm}$ ' dir. Donatılar, TS 708 "Çelik-Betonarme için-Donatı çeliği" standardına göre S420 kalitesindedir. Karışımlarda şehir şebeke suyu kullanılmıştır. Deneylerde kullanılan $\mathrm{NaCl}$ çözeltisi \%3,5 konsantrasyona sahiptir.

UYPB karışımları, 28 günlük standart kür sonrası basınç dayanımları $150 \mathrm{MPa} \pm \% 5$ olacak şekilde oluşturulmuştur. Kontrol karışımı $729 \mathrm{~kg} / \mathrm{m}^{3}$ çimento ve $182 \mathrm{~kg} / \mathrm{m}^{3} \mathrm{SD}$ içermekte olup su/bağlayıcı oranı 0,20 'dir. UK ve YFC ikameleri, kontrol karışımı hamur fazındaki çimento ağırlı̆̆ının sırasıyla \%30'u ve \%50'si oranında yapılarak benzer dayanım sınıfi elde edilmiştir. Hamur hacmi tüm karışımlarda $\% 55$ 'te sabit tutulmuştur. Puzolan kullanımı ve lif takviyesinin etkilerini belirlemek için üç adedi lifli, üç adedi lifsiz olmak üzere toplam altı adet karışım hazırlanmıştır. Lif takviyesi hacimce $\% 2$ olarak uygulanmış, gerekli hacim gradasyonu bozmayacak şekilde agrega hacminden düşülmüştür. Lifli karışımlarda $100 \mathrm{~mm}$ alt çapa sahip mini çökme konisi kullanılarak yapılan yayılma deneyi sonucu $250 \mathrm{~mm}$ kendiliğinden yayılma çapı hedefiyle akışkanlaştırıcı, farklı dozajlarda kullanılmıştır. Karışım oranları Tablo 3'te yer almaktadır. Karışımların hazırlanmasında yüksek devirde dönebilen, güçlendirilmiş bir mikser kullanılmıştır.

\subsection{Erken Yaş Büzülme Ölçümü \\ (Early Age Shrinkage Measurement)}

Çimentolu matrislerin erken yaş büzülme ölçümlerinde kullanılan yöntem lazer ölçüm sistemidir. Henüz erken dönemde plastik halde bulunan matrise dişarıdan deforme edici bir kuvvet uygulamadan ölçmek için lazer ile mesafe ölçümü mantığı kullanılmıştır (Şekil 1) [17, 18]. Çalışmalarda kullanılan erken yaş ( $<24$ saat) büzülme ölçüm kabininde ayn anda 5 adet numune $(25 \times 25 \times 290 \mathrm{~mm})$ test edilmiş, değerlendirmeler beş numunenin ortalama büzülme eğrileri kullanılarak yapılmıştır. Kullanılan sistem Şekil 2'de, büzülme kalıplarının ayrıntıları Şekil 3'te gösterilmektedir. Sistemde, kuruma koşullarında numune perdah yüzeyi kabin ortamına açıkken, bünyesel büzülme koşullarında (nem kaybının olmadığı) numunelerin yüzeyi 
Tablo 1. Çimentonun fiziksel ve kimyasal özellikleri (Physical and chemical properties of cement)

\begin{tabular}{|c|c|c|c|}
\hline Kimyasal özellikler & & Fiziksel özellikler & \\
\hline $\mathrm{SiO}_{2}(\%)$ & 19,1 & Özgül yüzey (Blaine) $\left(\mathrm{m}^{2} / \mathrm{kg}\right)$ & 369 \\
\hline $\mathrm{Al}_{2} \mathrm{O}_{3}(\%)$ & 4,40 & Priz başlangıcı (min) & 110 \\
\hline $\mathrm{Fe}_{2} \mathrm{O}_{3}(\%)$ & 3,96 & Priz sona ermesi (min) & 166 \\
\hline $\mathrm{CaO}(\%)$ & 61,85 & Hacim Genleşmesi (mm) & 1,00 \\
\hline $\mathrm{MgO}(\%)$ & 2,05 & & \\
\hline $\mathrm{Na}_{2} \mathrm{O}(\%)$ & 0,27 & & \\
\hline $\mathrm{K}_{2} \mathrm{O}(\%)$ & 0,70 & Basınç Dayanımı & \\
\hline $\mathrm{SO}_{3}(\%)$ & 3,72 & 2 gün $(\mathrm{MPa})$ & 27,1 \\
\hline $\mathrm{Cl}^{-}(\%)$ & 0,0004 & 7 gün (MPa) & 43,3 \\
\hline Kızdirma kaybı (\%) & 1,82 & 28 gün $(\mathrm{MPa})$ & 56,0 \\
\hline
\end{tabular}

Tablo 2. Mineral katkıların fiziksel ve kimyasal özellikleri (Physical and chemical properties of mineral admixtures)

\begin{tabular}{llll}
\hline Kimyasal Kompozisyon (\%) & Silis Duman1 & Yüksek Firın Cürufu & Uçucu Kül \\
\hline $\mathrm{SiO}_{2}$ & 92,26 & 39,82 & 47,15 \\
$\mathrm{Al}_{2} \mathrm{O}_{3}$ & 0,89 & 9,36 & 20,42 \\
$\mathrm{Fe}_{2} \mathrm{O}_{3}$ & 1,97 & 0,90 & 4,15 \\
$\mathrm{CaO}$ & 0,49 & 36,61 & 20,47 \\
$\mathrm{MgO}$ & 0,96 & 6,38 & 1,51 \\
$\mathrm{Na}_{2} \mathrm{O}$ & 0,42 & - & 0,59 \\
$\mathrm{~K}_{2} \mathrm{O}$ & 1,31 & - & 1,36 \\
$\mathrm{SO}_{3}$ & 0,33 & 0,16 & 2,08 \\
$\mathrm{Cl}^{-}$ & 0,09 & 0,013 & 0,015 \\
\hline Fiziksel Özellikler & & 292 \\
\hline Özgül yüzey (m²/kg) & 20000 & 599 & 83 \\
Dayanim aktivite indeksi, ASTM C-311 & 95 & 120 & \\
(28 gün), (\%) & 95 &
\end{tabular}

Tablo 3. Karışım oranları (Mix designs)

\begin{tabular}{|c|c|c|c|c|c|c|}
\hline \multirow{2}{*}{$\begin{array}{l}\text { Malzemeler } \\
\left(\mathrm{kg} / \mathrm{m}^{3}\right)\end{array}$} & \multicolumn{3}{|l|}{ LIFLİ } & \multicolumn{3}{|c|}{ LİFSİZ } \\
\hline & C-F2 & UK30-F2 & YFC50-F2 & C-F0 & UK30-F0 & YFC50-F0 \\
\hline$\overline{\mathrm{Su}}$ & 182 & 171 & 183 & 182 & 171 & 183 \\
\hline Çimento & 729 & 480 & 365 & 729 & 480 & 365 \\
\hline Uçucu kül & - & 206 & - & - & 206 & - \\
\hline Yüksek firın cürufu & - & - & 365 & - & - & 365 \\
\hline Silis dumanı & 182 & 171 & 183 & 182 & 171 & 183 \\
\hline 5-8 mm kuvars & 230 & 230 & 230 & 240 & 240 & 240 \\
\hline 1-3 mm kuvars & 230 & 230 & 230 & 240 & 240 & 240 \\
\hline $0,5-1 \mathrm{~mm}$ kuvars & 380 & 380 & 380 & 397 & 397 & 397 \\
\hline $0-0,4 \mathrm{~mm}$ kuvars & 310 & 310 & 310 & 324 & 324 & 324 \\
\hline Akışkanlaştırıcı & 27 & 33 & 17 & 27 & 33 & 17 \\
\hline Mikro çelik lif & 143 & 143 & 143 & - & - & - \\
\hline Su/bağlayıcı & 0,20 & 0,20 & 0,20 & 0,20 & 0,20 & 0,20 \\
\hline $\mathrm{Su} /$ çimento & 0,25 & 0,36 & 0,50 & 0,25 & 0,36 & 0,50 \\
\hline
\end{tabular}

naylon örtü ile kapatılmıştır [17, 18]. Erken yaş bünyesel büzülme ölçümleri $20^{\circ} \mathrm{C}-\% 98$ bağıl nem (BN), kuruma büzülmesi ölçümleri ise $30^{\circ} \mathrm{C}-\% 50 \mathrm{BN}$ kabin koşullarında ölçülmüştür. Priz başlangıç ve bitiş süreleri TS EN 480-2 standardına göre $20^{\circ} \mathrm{C}$ ve $30^{\circ} \mathrm{C}$ sıcaklığa sahip termal banyo içerisinde tespit edilmiştir. İlgili büzülme ortamı sıcaklığında ölçülen priz başlangıcı anında Şekil 3'te sunulan lazer ışın yolu önündeki engel kaldırılmış ve kayıt başlatılmıştır.
2.3. Donatılı Beton Numunelerinin Hazırlanması ve Kürü (Preparation and Curing of Reinforced Concrete Specimens)

Çalışmanın akışı Şekil 4'teki diyagramda özetlenmektedir. Karışımlar hazırlandıktan sonra kısıtlanmış ve serbest kalıp düzeneklerine yerleştirilmiştir. Serbest kalıp düzenekleri ideal ortamda, büzülme kısıtlayan kalıplar ise iklimlendirme kabininde oluşan kuruma ortamında 24 saat muhafaza 
edilmiştir. 24 saat sonra kalıptan çıkarılan numuneler korozyon deneyleri öncesinde folyo ile kaplama, donat1 epoksileme ve kablolama işlemlerine tabi tutulmuştur. $\mathrm{Bu}$ şekilde 28 gün laboratuvar ortamında yalıtılmış halde bekletilen numunelerin alüminyum folyo kaplamaları sökülerek çatlak analizleri, yüzeylerin fotoğraflanması işlemleri yapılmıştır. Daha sonrasında 24 saat \%3,5 $\mathrm{NaCl}$ çözeltisinde bekletilen numuneler doygun halde doğrudan korozyon deneylerine tabi tutulmuştur. Her bir karışım ve erken yaş koşulu için 6'şar adet donatılı numune test edilmiştir.

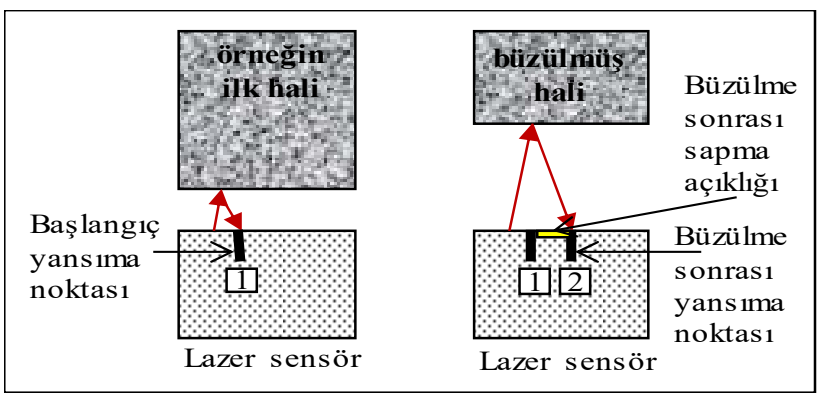

Şekil 1. Lazer sensör ile büzülme ölçümü

(Measurement of shrinkage by the laser sensor)

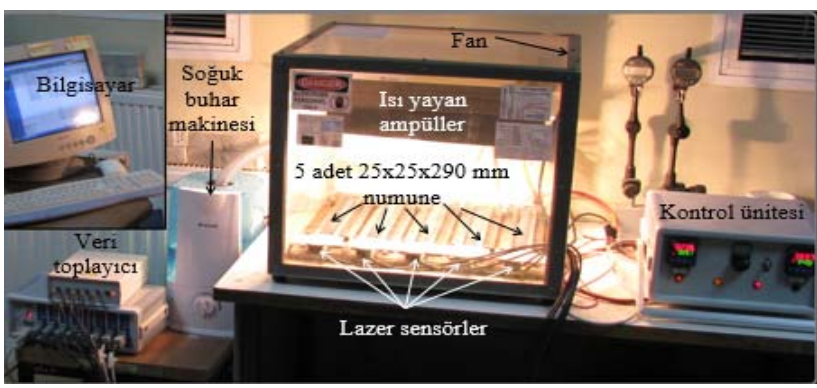

Şekil 2. Erken yaş büzülme test kabini

(Early age shrinkage test cabinet)

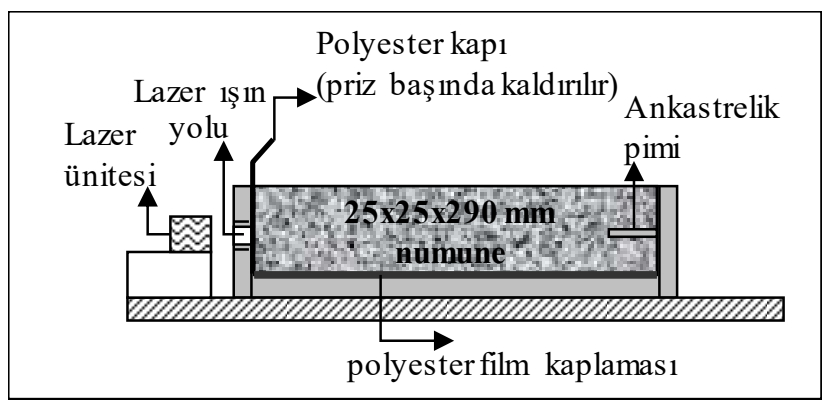

Şekil 3. Erken yaş büzülme kalıbı (Early age shrinkage mould)

$240 \mathrm{~mm}$ uzunluğunda, $10 \mathrm{~mm}$ çapındaki çelik donatılar kalıplara yerleştirilmeden önce hassas bir şekilde alkol ile yıkanıp temizlenmiş ve temiz havlular üzerinde kurutulmuştur. Temizlenip tartılarak kodlanan çelik donatılar döküm yüzeyinden itibaren $1 \mathrm{~cm}$ paspayı kalacak şekilde kalıba yerleştirilmiştir. Kısıtlayıcı kalıp sistemi, prizmatik şekilli, $75 \times 75 \times 205 \mathrm{~mm}$ iç hacimli, eksenel yönde numuneyi kısıtlamaya çalışan bir tasarıma sahiptir (Şekil 5). Kalıp alınlarının merkezinde büzülme kısıtlayıcı etki 1350 yaratmak üzere rondelal1-vidalı pimler mevcuttur. Hazırlanan karışımlar kalıpların orta kısmından dökülmüştür. $\mathrm{Bu}$ sayede liflerin yönelimlerinin her bir numunede aynı şekilde olması sağlanmıştır. Karıșımlar kalıplara kendiliğinden yerleşmiştir (Şekil 6). Ancak sıkışık havanın atılması için kalıp yanlarına plastik çekiç ile birkaç kez hafifçe vurulmuştur.

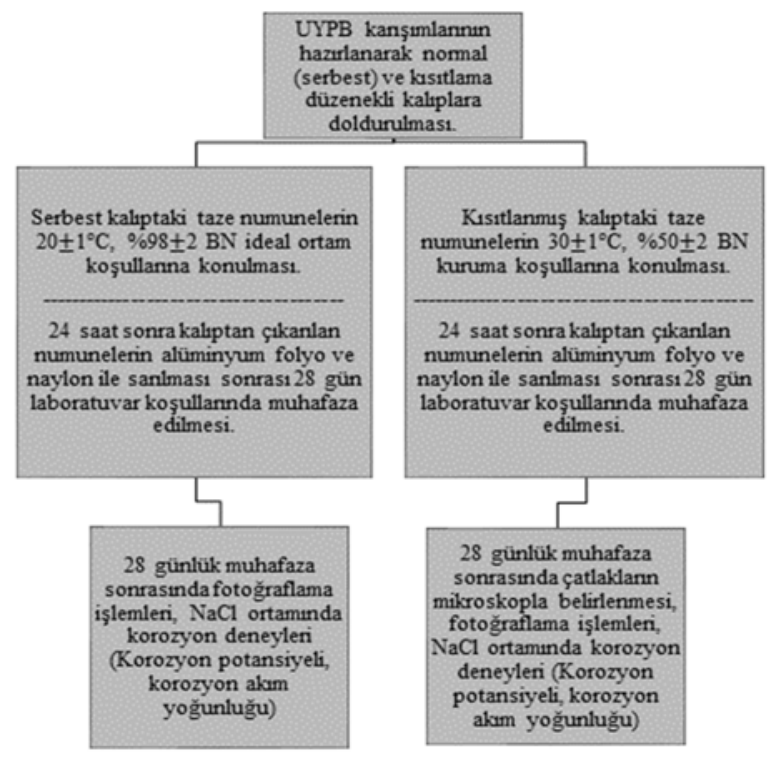

Şekil 4. Deneysel çalışma akış diyagramı

(Flow diagram of experimental study)

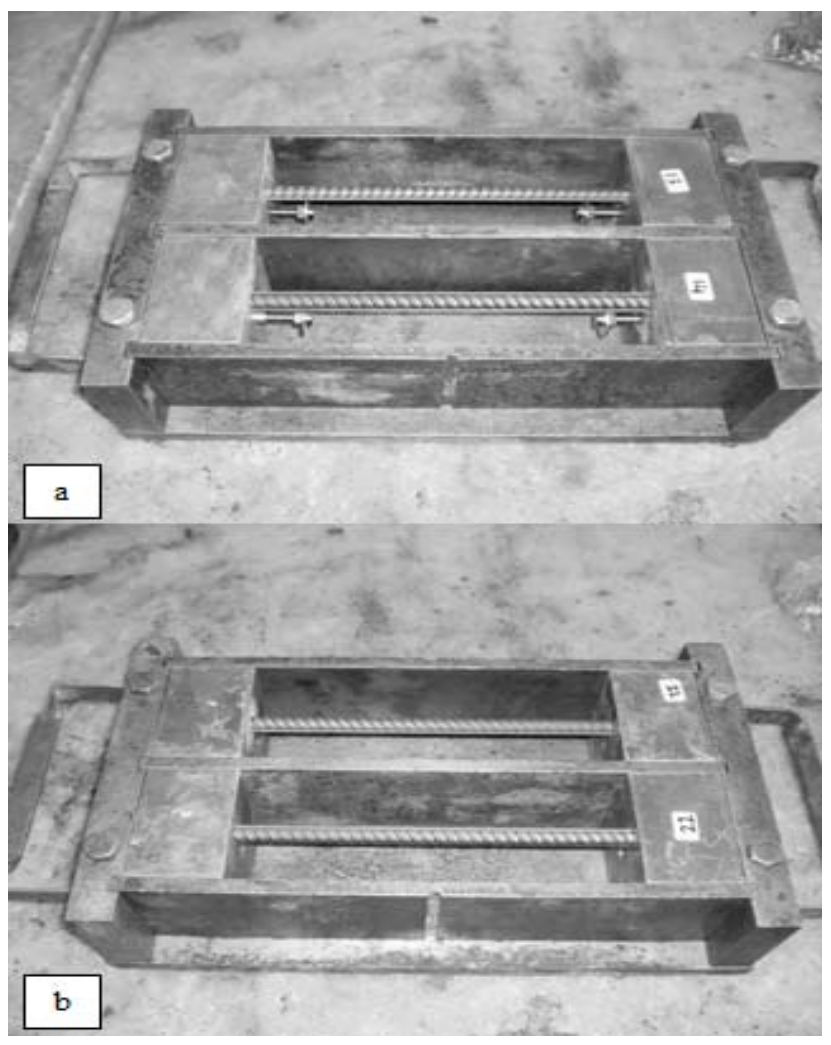

Şekil 5. Kısıtlanmış a) ve serbest b) numune kalıpları (Restricted a) and non-restricted b) specimen moulds) 
Serbest kalıp sistemlerindeki numuneler yalıtılmış olarak kür kabininin ideal ortamında $\left(20 \pm 1^{\circ} \mathrm{C}, \% 98 \pm 2\right.$ bağıl nem) 24 saat boyunca bekletilmiştir. Kısıtlı kalıp sistemlerindeki numuneler ise kuruma ortamiyla $\left(30 \pm 1^{\circ} \mathrm{C}, \% 50 \pm 2\right.$ bağ 1 nem) sadece $75 \times 205 \mathrm{~mm}$ 'lik üst yüzeyden temas halinde olacak şekilde 24 saat boyunca tutulmuştur (Şekil 7). Streç film üzerine alüminyum folyo giydirilen numuneler laboratuvar ortamında 28 gün bekletilmiştir. $\mathrm{Bu}$ işlemin sebebi ölçümler öncesi donatıda veya liflerde oluşabilecek oksidasyonu engellemek ve betona yalıtılmış bir kür ortamı sağlamaktır. Numune kaplama ve kablolama aşamalarından sonra donatıların açıkta kalan kısımları epoksi esaslı iki bileşenli koruyucu kaplama malzemesi (POLISPORT-EPSK 1400 RAL) ile kaplanmış, böylelikle \%3,5 konsantrasyona haiz $\mathrm{NaCl}$ çözeltisinin yalnızca numunenin yan yüzeylerinden işlemesi sağlanmıştır (Şekil 8).

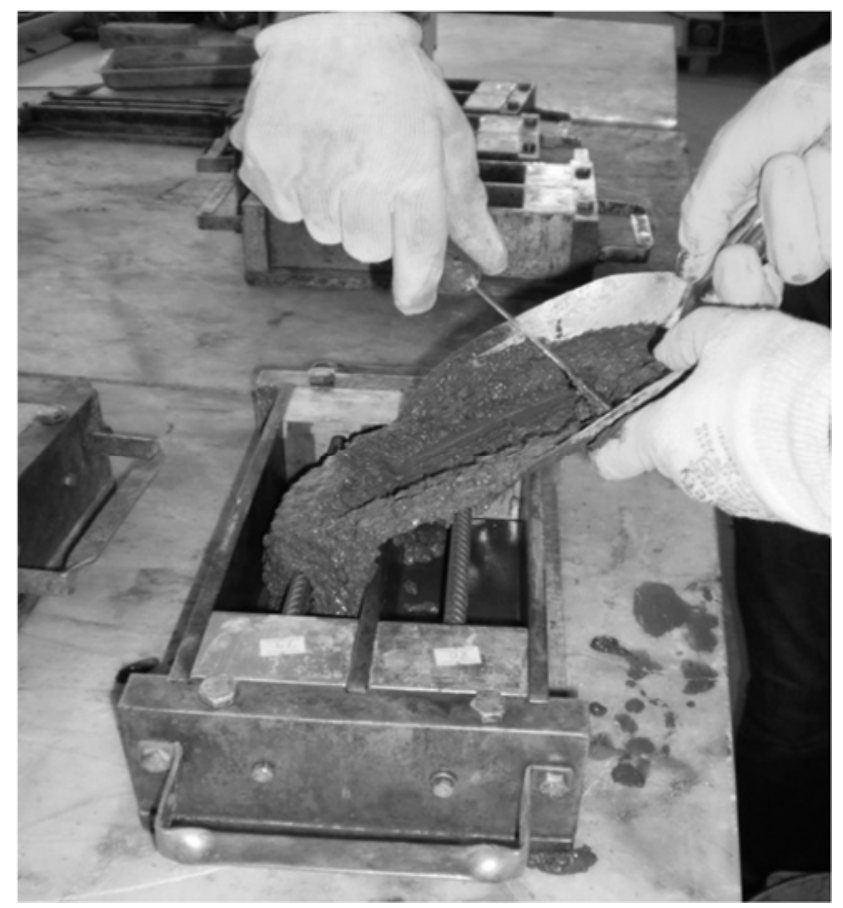

Şekil 6. Karışımların kalıplara yerleştirilmesi (Pouring of mixtures into the moulds)

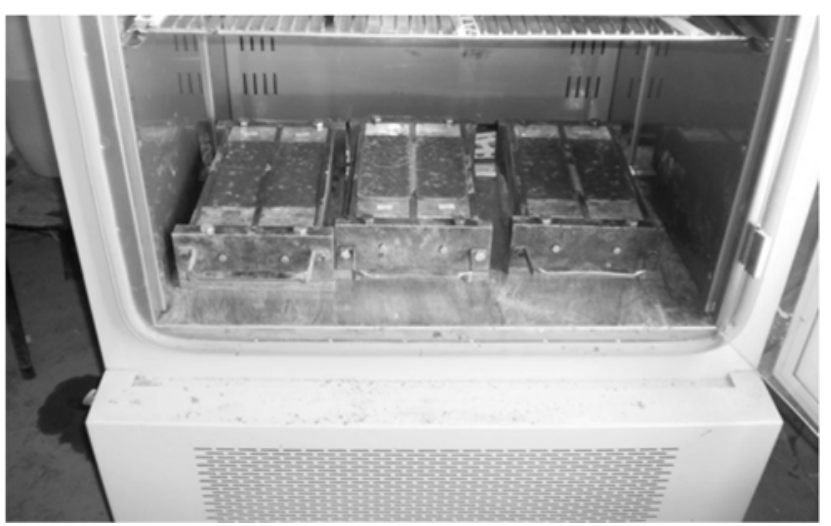

Şekil 7. Taze karışımların iklimlendirme kabinine yerleștirilmesi

(Placement of fresh mixtures into the climate cabinet)
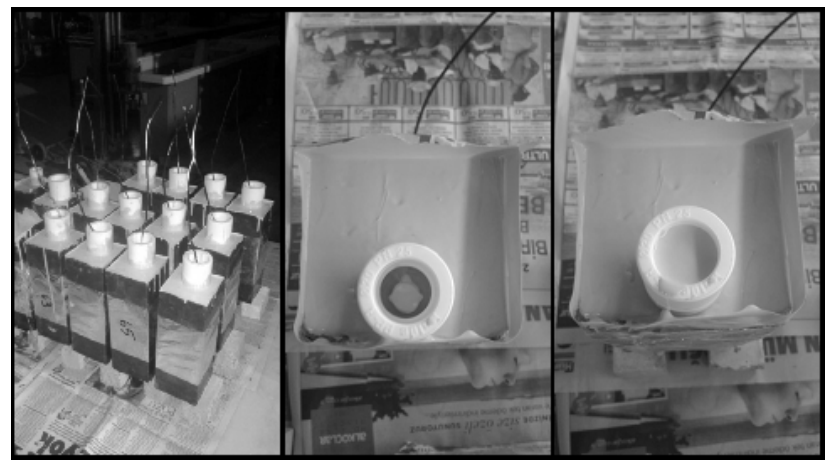

Şekil 8. Epoksi ile donatı uçlarını kaplama işlemi (Coating of free end of rebars with epoxy)

\subsection{Korozyon Ölçümleri (Corrosion Measurements)}

Numuneler, 28 gün laboratuvar koşullarında yalıtılmış olarak bekletildikten sonra şehir şebeke suyu ile hazırlanan \%3,5 oranındaki $\mathrm{NaCl}$ çözeltisine daldırılmıştır. 24 saat sonra doygun numuneler, vakit kaybı olmaksızın deney cihazına yerleştirilmiştir.

Korozyon hızlarının tespit edilmesine yönelik deneylerde elektrolitik ortam, şehir şebeke suyu ile hazırlanmış \%3,5 $\mathrm{NaCl}$ çözeltisidir. Korozyon ölçümleri üç elektrotlu sistem kullanılarak gerçekleştirilmiştir (Şekil 9). Ölçümlerde, Gamry REF 600 ve Gamry Interface 1000 Potentiostat/Galvonastat/ZRA sistemleri kullanılmıştır. Referans elektrot doygun kalomel elektrot (SCE) olup, karşı1 elektrot grafittir (Şekil 10).

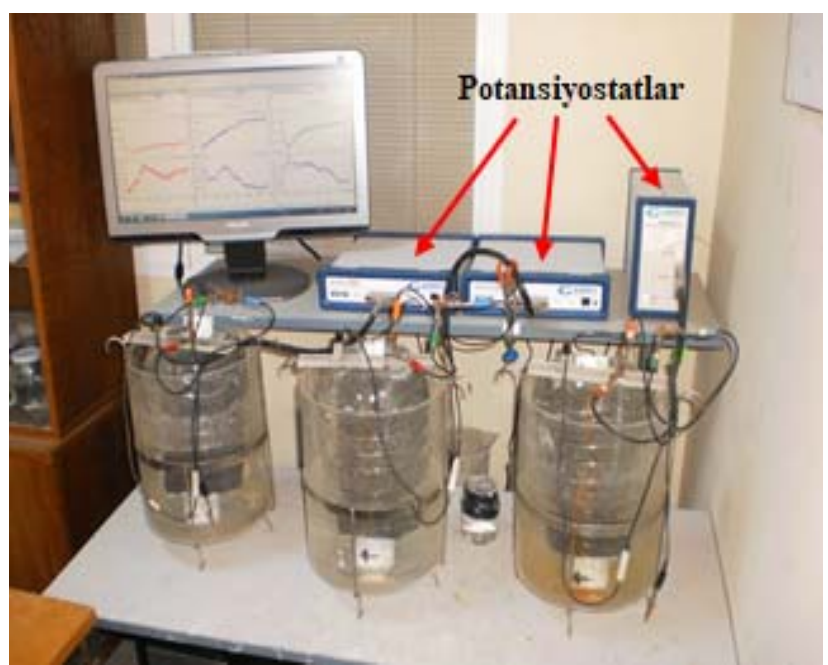

Şekil 9. Korozyon ölçüm sistemi (Corrosion measurement system)

Referans korozyon ölçüm yöntemi olan kütle kaybının belirlenmesi, hassas şekilde ağırlığı ölçülmüş bir donatının korozyona uğrayacağı ortama bırakılarak, belirli bir süre sonra çıkarılması ve yeniden tartım ile kaybedilmiş metal kütlesinin hesaplanması şeklindedir. Numune yüzeyinde biriken korozyon ürünleri, genellikle kimyasal ve elektrokimyasal yöntemlerle temizlenir. Gerekirse mekanik temizleme veya mekanik+kimyasal temizleme de kullanılabilir. 


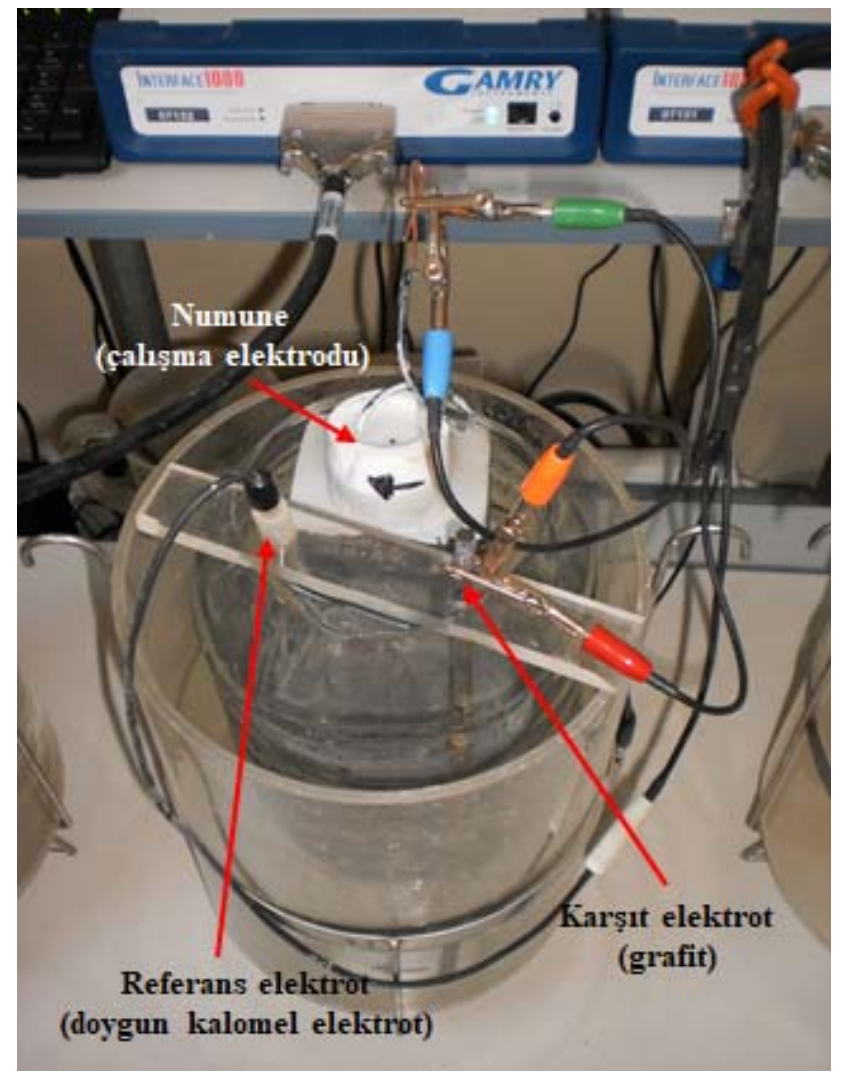

Şekil 10. Deney düzeneğini oluşturan elektrotlar (Electrodes which constitute experimental system)

Metal yüzeyinin her tarafında sabit hızla çözünmenin olduğu koşullarda korozyon hızı, ağırlık kaybı olarak tanımlanabilir (Eş. 1). Birim zamanda (t) birim alanda (A) gerçekleşen kütle kaybı $(\Delta \mathrm{W})$, korozyon hızı (CR) olarak tanımlanır [19].

$$
\mathrm{CR}=\Delta \mathrm{W} /(\mathrm{A} . \mathrm{t})
$$

Elektrokimyasal ölçüm teknikleri kullanıldığında, elektrokimyasal parametrelerin gravimetrik hale dönüştürülmesi Faraday Yasası kullanılarak yapılır (Eş. 2). Eş. 2'de akım (I), zaman (t), kütle kaybı $(\Delta \mathrm{W})$ değerleri sirasiyla amper, saniye, gram birimlerinde, Faraday sabiti (F) ise 96500 coulomb değerindedir. Eşitlikte, " $W_{m}$ " ve " $\mathrm{z}$ " ise sırasıyla metalin moleküler ağırlığını ve değerliği ifade etmektedir.

$$
\mathrm{I} . \mathrm{t} / \mathrm{F}=\Delta \mathrm{W} /\left(\mathrm{W}_{\mathrm{m}} / \mathrm{z}\right)
$$

Eşitliğin içerdiği akım, korozyon yoğunluğu $\left(\mathrm{I}_{\text {corr }}\right)$ olarak isimlendirilir ve üniform korozyon kabul edildiğinde korozyon hizı $\mu \mathrm{m} / \mathrm{cm}^{2}$ veya $\mu \mathrm{m} / \mathrm{y} 1$ birimlerinde verilebilir. Eğer korozyon homojen ise deneylerden bulunan akım, korozyona uğrayan metalik yüzey ile ilgilidir ve dolayısıyla $\mu \mathrm{A} / \mathrm{cm}^{2}$ biriminde verilebilir [12]. Korozyonun gelişmesi hakkında bilgi sağlayan en önemli yöntemlerden biri de polarizasyon tekniğidir. Polarizasyon eğrileri elektrokimyasal hücre içinde anot ve katodun polarizasyonu sonucu gelişen, akımın şiddeti ile potansiyeli arasındaki bağıntıyı gösteren eğrilerdir. Üç elektrotlu sistemle elde edilen polarizasyon eğrilerinin analizi ile beton içindeki çeliğin bulunduğu ortam koşullarında anlık korozyon akım yoğunluğunu ve korozyon hızını tespit etmek mümkündür [20, 21]. Korozyon çalışmalarının birinci bölümünde bir ucuna bakır kablo bağlanarak üretilen donatıların polarizasyon eğrileri elde edilmiştir. Öncelikle numunelerin açık devre potansiyeli $\left(\mathrm{E}_{\text {ocp }}\right)$ değeri 3600 saniye süresince ölçülmüş, ardından açık devre potansiyeline göre $-0,25 \mathrm{~V}$ ile $+0,25 \mathrm{~V}$ arasında, $0,2 \mathrm{mV} / \mathrm{s}$ potansiyel artış hızı ile potansiyodinamik tarama eğrileri çıkarılmıştır. İkinci aşamada, numunelere zorlanmış bir potansiyel uygulanarak hızlandırılmış korozyon deneyleri gerçekleştirilmiştir. Donat1l numunelerin $10 \mathrm{~V}$ sabit potansiyel altında 86400 saniye süresince akım-zaman grafikleri elde edilmiştir. Numunedeki korozyon miktarının belirlenmesinde bu potansiyostatik tarama eğrileri kullanılmıştır. Faraday Yasası kullanılarak (Eş. 2) çelik numunedeki tahmini kütle kayıpları hesaplanmıştır. Deney sonunda numune kırılmış ve donatılar temizlenerek gerçek kütle kayıpları belirlenmiştir.

\subsection{Karışımların Mekanik Özelliklerin Belirlenmesi (Determination of Mechanical Properties of the Mixtures)}

Basınç ve eğilme dayanımının tespiti için karışımlardan $40 \times 40 \times 160 \mathrm{~mm}$ ebatlarında 3 'er adet prizmatik numune alınmıştır. Numuneler 28 gün standart su kürüne tabi tutulmuştur. Kür sonrasında üç noktalı eğilme deneyi gerçekleştirilmiş, deney sonucu oluşan altışar parçada, $40 \times 40 \mathrm{~mm}^{2}$ 'lik alanda basınç deneyi uygulanmıştır.

\section{SONUCLAR VE TARTISMALAR (RESULTS AND DISCUSSIONS)}

\subsection{Mekanik Özellikler (Mechanical Properties)}

C-F2, UK30-F2 ve YFC50-F2 karışımları ile üretilen örneklerin 28 günlük standart kür sonrası ortalama eğilme dayanımları sırasıyla 21,6, 21,9, 22,4 MPa; ortalama basınç dayanımları ise 148, 151, $157 \mathrm{MPa}$ 'dır. C-F0, UK30-F0 ve YFC50-F0 karışımları ise standart kür sonrası sırasıyla 21, 21,3 ve 21,4 MPa eğilme dayanımı ve 111,121 ve $132 \mathrm{MPa}$ basınç dayanımı sergilemiştir.

\subsection{Karışımların Erken Yaş Büzülme Davranışı (Early Age Shrinkage Behaviour of the Mixtures)}

UYPB karışımlarının erken yaş büzülme özellikleri incelenmiştir. Geliştirilen karışımların gerek bünyesel büzülme, gerekse kuruma büzülmesi mertebeleri oldukça yüksek seviyelerdedir. Şekil 11'de lazer sistemiyle ölçülen lifsiz ve lifli UYPB karışımlarının erken dönem bünyesel büzülme $\left(20 \pm 1^{\circ} \mathrm{C}, \% 98 \pm 2\right.$ bağıl nem) ölçüm sonuçları sunulmaktadır. UK ikamesi ile erken yaş bünyesel büzülme kontrol karışımına kıyasla azalırken, YFC ikamesi ile artmıştır. [17, 18]. Yüksek inceliği, kapiler boşluk daraltıcı özelliği ve yüksek puzolanik aktivitesi sebebiyle YFC ikamesi bünyesel büzülme değerini önemli oranda arttırmıştır [22, 23]. Şekil 12'de lifsiz ve lifli UYPB karışımlarının erken yaş kuruma büzülmesi $\left(30^{\circ} \mathrm{C}, \% 50\right.$ 

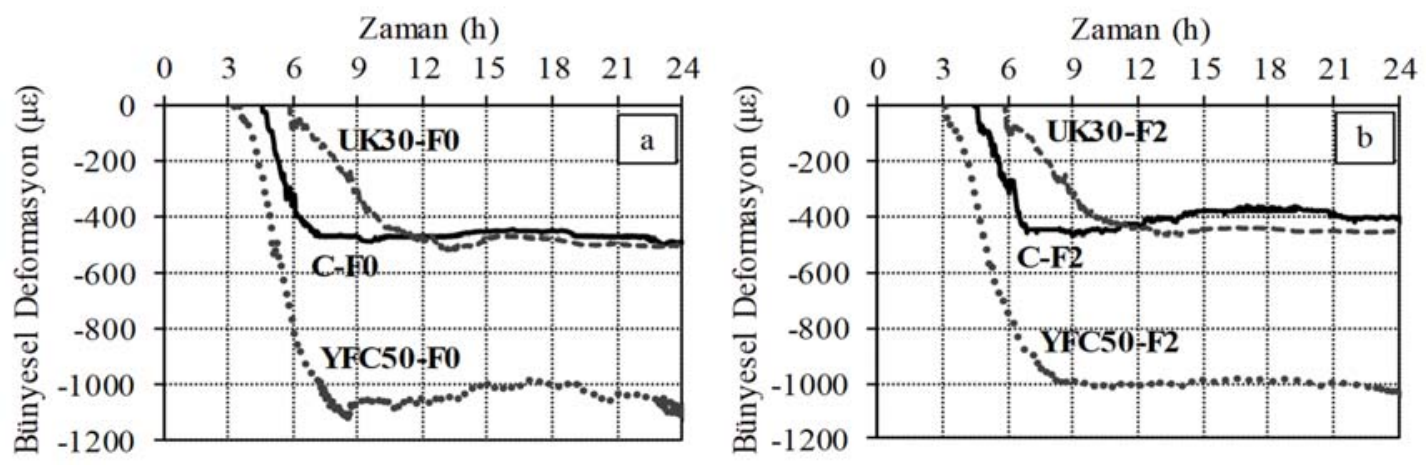

Şekil 11. Lif içermeyen a) ve lifli b) UYPB karışımlarının erken yaş bünyesel büzülmesi (Early age autogenous shrinkage of fiberless (a) and fiber reinforced (b) UHPC mixtures)
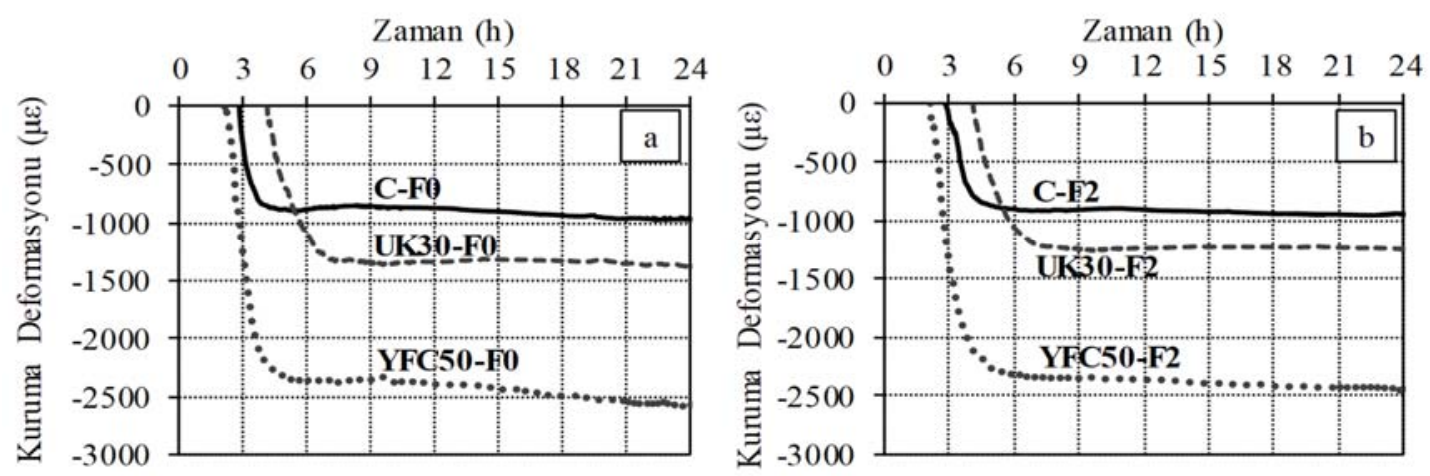

Şekil 12. Lif içermeyen a) ve lifli b) UYPB karışımlarının erken yaş kuruma büzülmesi (Early age drying shrinkage of fiberless (a) and fiber reinforced (b) UHPC mixtures)

bağıl nem) grafikleri verilmektedir. Puzolan ikamesi ile kür hassasiyetinin arttı̆̆ 1 görülmektedir. UYPB karışımlarında YFC ikamesi sonucu erken dönem bünyesel büzülme ve kuruma büzülmesi değerleri önemli oranda artmıştır. $\mathrm{Su} /$ bağlayıcı oranı çok düşük UYPB türü kompozitlerde kuruma ortamındaki toplam büzülmeyi etkileyen en önemli faktörler bünyesel büzülme ve kimyasal bağlı su miktarıdır. İkame oranının artışı ile çimento dozajı azıldığında erken yaş kuruma ortamında buharlaşabilen su miktarı artabilir. Katk1 ihtiyacını arttıran UK ikamesinin YFC ikamesine göre daha az kuruma büzülmesi yaratmasının diğer bir sebebi, kalıp yüzeyinden fiziksel su kaçışının yüksek akışkanlaştırıcı oranlarında oluşan fil derisi sebebiyle azalması olabilir. Ayrıca düşük nem ortamında içsel kurumanın YFC ikamesiyle daha şiddetli gelişmesi beklenmektedir. Lif takviyesinin erken yaş büzülmeyi azaltmada önemli bir katkı sunmadığı görülmektedir. Ancak liflerden genellikle beklenen, kısıtlanmış durumda çatlak oluşumunu engellemesi veya çatlak açıklıklarını sınırlandırmasıdır. Yüksek oranda puzolan içeren karışımlarda ilk 24 saat kür uygulaması önem kazanmaktadır [17, 18].

\subsection{Büzülme Çatlaklarının İncelenmesi (Analysis of Shrinkage Cracks)}

Erken yaşta $30^{\circ} \mathrm{C}, \% 50$ bağ 1 nem ortamında ankastrelik pimleri ile kısıtlanmış halde 24 saat bekletilmiş numunelerde çatlak uzunluk ve açıklıkları korozyon deneyleri öncesi (28. gün) incelenmiştir. Dijital çatlak mikroskobu ile sistematik taramalar gerçekleştirilmiştir. Numune yüzeyleri: perdah yüzeyi (0), yan yüzeyler (1 ve 2) ve alt yüzey (3) olmak üzere üç ana grupta değerlendirilmiştir (Şekil 13). Her bir yüzeydeki çatlak uzunlukları ölçülmüştür. Ortalama çatlak açıklıkları ise yön değiştirmemiş ve benzer karakterdeki her bir çatlaktan alınan en az üç ölçüm ile belirlenmiştir. Her bir çatlak için tespit edilen ortalama çatlak açıklıkları, çatlak sayısına bölünerek ilgili yüzeyin ortalama çatlak açıklığ tespit edilmiştir. Çatlak uzunluğu, ortalama çatlak açıklığıyla çarpılarak çatlak yüzey alanı bulunmuştur. Kısıtlanmış büzülme sonucu lifli UYPB'lerin farklı yüzeylerinde oluşan çatlakların uzunluk, genişlik ve alanlarının değişimi Tablo 4'te sunulmaktadır. Lifsiz UYPB'lerin kısıtlanmış büzülme sonucu farklı yüzeylerinde oluşan çatlakların uzunluk, genişlik ve alanlarının değişimi ise Tablo 5'te sunulmaktadır.

Şekil 14 incelendiğinde lif takviyesinin çatlak yüzey alanını azaltmadaki etkinliği görülmektedir. Lifsiz karışımlar arasında ikamesiz kontrol karışımı en büyük çatlak yüzey alanına $\left(87,8 \mathrm{~mm}^{2}\right)$ sahiptir. Puzolan ikamesinin çatlak yüzey alanlarını sınırlayıcı etkisi vardır. En iyi performansı uçucu kül ikameli, lif takviyeli karışım sergilemiştir. Tüm yüzeyler fotoğraflanarak genel görünüm kayıt altına alınmıştır. En geniş çatlak açıklıklarının bulunduğu lifsiz numunelerin kuruma-kısitlı durumunda üst yüzeylerinin fotoğrafları Şekil 15 ve 16'da yer almaktadır. 


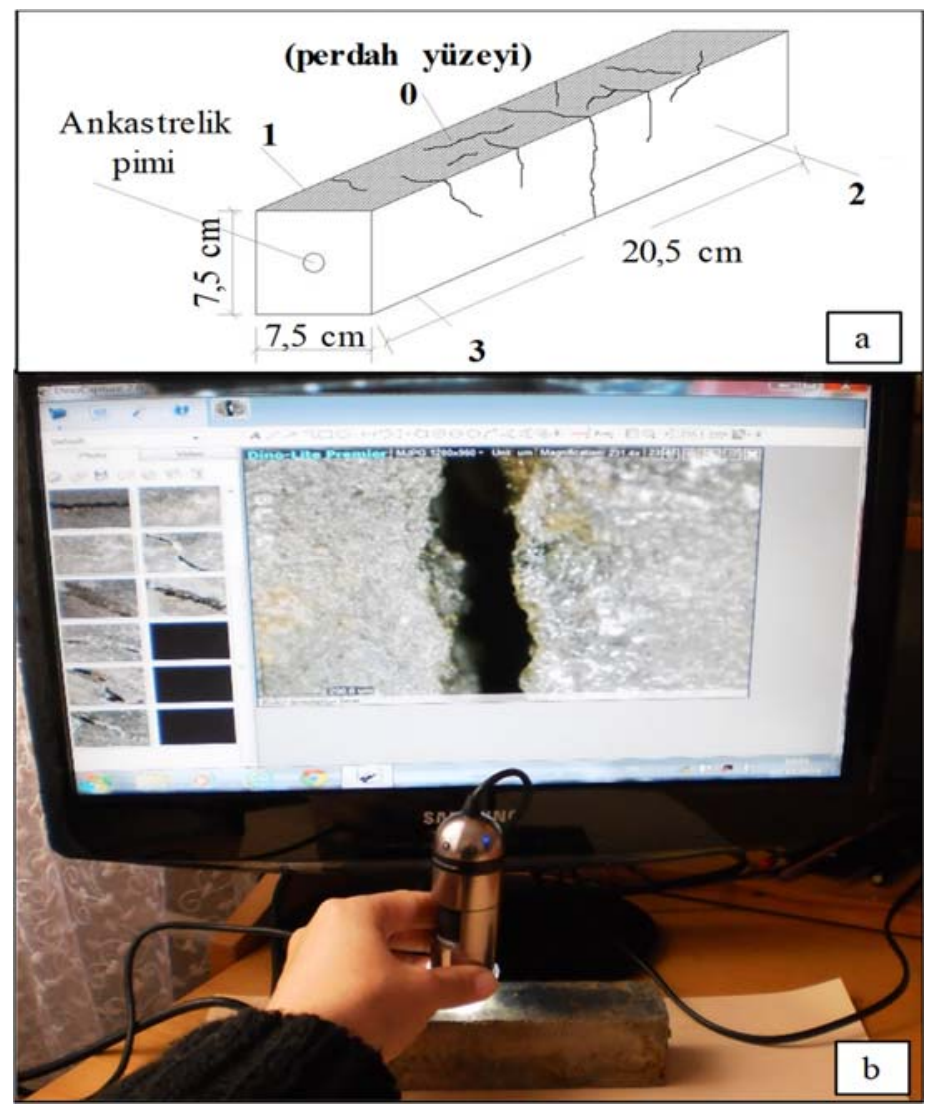

Şekil 13. Kısıtlanmış numunelerde yüzey isimlendirmesi a) ve çatlak açıklıklarının ölçümü b) (Naming of restricted specimens' surface a) and measurement of crack widths b))

Tablo 4. Lifli numunelerin çatlak analizleri (Crack analysis of fiber reinforced specimens)

\begin{tabular}{llllll}
\hline & & Üst Yüzey & Yan Yüzey & Alt Yüzey & Toplam \\
\hline \multirow{3}{*}{ C-F2 } & Çatlak Uzunluğu $(\mathrm{mm})$ & 158,5 & 68,4 & 45,0 & 271,9 \\
& Ortalama Çatlak Çapı $(\mu \mathrm{m})$ & 141,3 & 49,5 & 45,3 & \\
& Çatlak Yüzeyi Alanı $\left(\mathrm{mm}^{2}\right)$ & 22,4 & 3,4 & 2,0 & 27,8 \\
\hline \multirow{3}{*}{ UK30-F2 } & Çatlak Uzunluğu $(\mathrm{mm})$ & 31,6 & 8,0 & 0,0 & 39,6 \\
& Ortalama Çatlak Çapı $(\mu \mathrm{m})$ & 67,3 & 39,7 & 0,0 & \\
& Çatlak Yüzeyi Alanı $\left(\mathrm{mm}^{2}\right)$ & 2,1 & 0,3 & 0,0 & 2,4 \\
\hline \multirow{3}{*}{ YFC50-F2 } & Çatlak Uzunluğu $(\mathrm{mm})$ & 129,2 & 44,6 & 0,0 & 173,8 \\
& Ortalama Çatlak Çapı $(\mu \mathrm{m})$ & 121,8 & 81,7 & 0,0 & \\
& Çatlak Yüzeyi Alanı $\left(\mathrm{mm}^{2}\right)$ & 15,7 & 3,6 & 0,0 & 19,4 \\
\hline
\end{tabular}

Tablo 5. Lifsiz numunelerin çatlak analizleri (Crack analysis of fiberless specimens)

\begin{tabular}{llllll}
\hline & & Üst Yüzey & Yan Yüzey & Alt Yüzey & Toplam \\
\hline \multirow{3}{*}{ C-F0 } & Çatlak Uzunluğu $(\mathrm{mm})$ & 239,0 & 183,4 & 53,0 & 475,4 \\
& Ortalama Çatlak Çapı $(\mu \mathrm{m})$ & 314,2 & 60,6 & 29,5 & \\
& Çatlak Yüzeyi Alanı $\left(\mathrm{mm}^{2}\right)$ & 75,1 & 11,1 & 1,6 & 87,8 \\
\hline \multirow{3}{*}{ UK30-F0 } & Çatlak Uzunluğu $(\mathrm{mm})$ & 50,0 & 0,0 & 0,0 & 50,0 \\
& Ortalama Çatlak Çapı $(\mu \mathrm{m})$ & 179,8 & 0,0 & 0,0 & \\
& Çatlak Yüzeyi Alanı $\left(\mathrm{mm}^{2}\right)$ & 9,0 & 0,0 & 0,0 & 9,0 \\
\hline \multirow{3}{*}{ YFC50-F0 } & Çatlak Uzunluğu $(\mathrm{mm})$ & 252,5 & 145,8 & 83,3 & 481,6 \\
& Ortalama Çatlak Çapı $(\mu \mathrm{m})$ & 167,4 & 80,2 & 57,1 & \\
& Çatlak Yüzeyi Alanı $\left(\mathrm{mm}^{2}\right)$ & 42,3 & 11,7 & 4,8 & 58,7
\end{tabular}




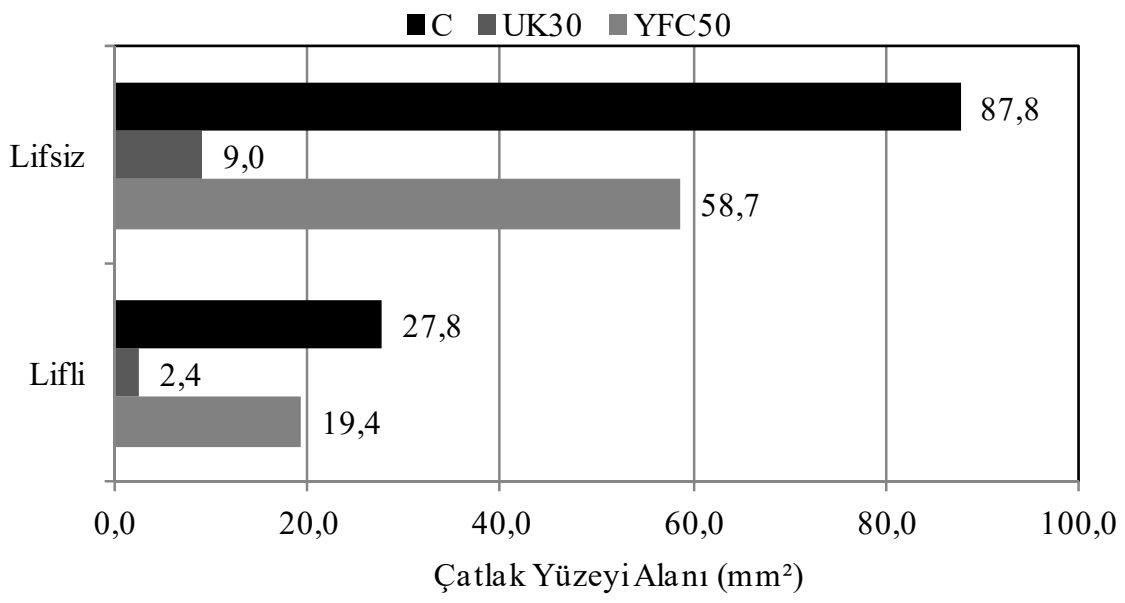

Şekil 14. İlk 24 saat kuruma koşulunda kısıtlı halde bekletilen numunelerin çatlak yüzey alanları (Crack surface areas of restricted specimens which were kept in drying condition for 24 hours)

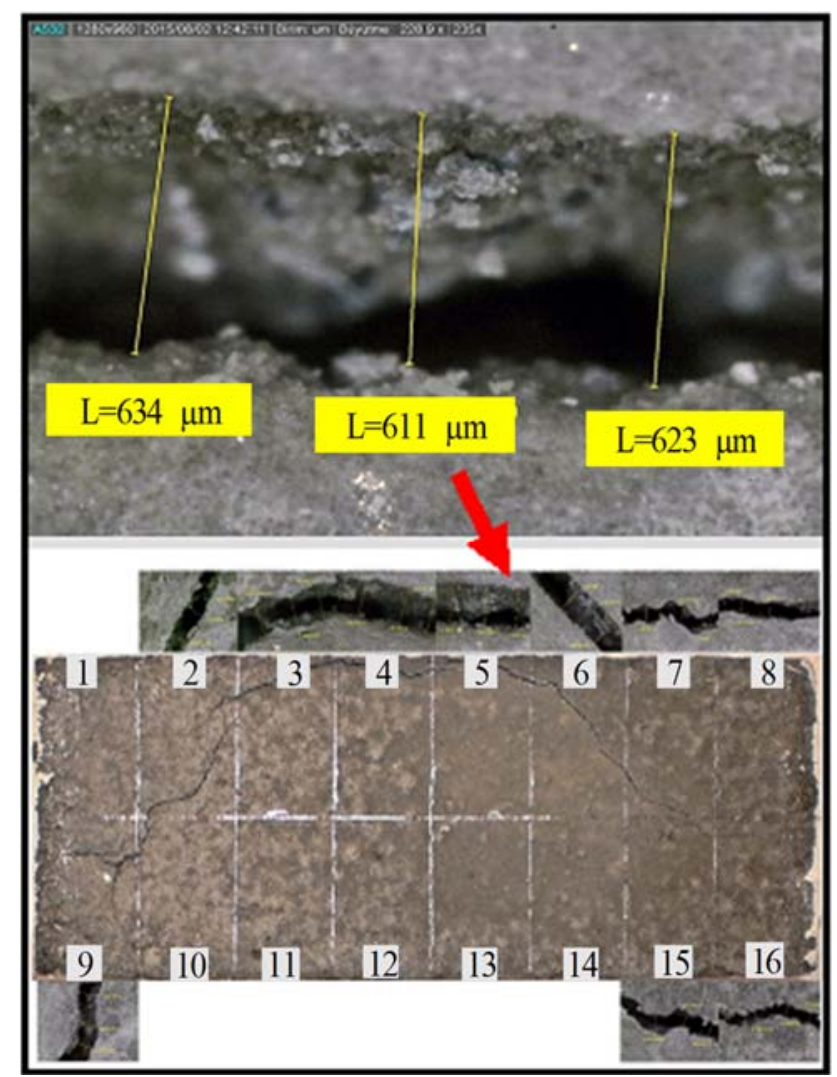

Şekil 15. C-F0 karışımının en geniş çatlak açıklığı ve numune üzerindeki yeri

(The largest crack witdh of C-F0 mixture and its location)

\subsection{Korozyon Deneyinin Değerlendirilmesi (Evaluation of Corrosion Experiments)}

Şekil 17'de örnek bir polarizasyon eğrisi ve eğri üzerinde gerçekleştirilen Tafel analizi görülmektedir. Betonarme numunelerden elde edilen polarizasyon eğrileri lifli ve lifsiz karıșımlar için sırasıyla Şekil 18 ve 19 'da sunulmaktadır. Lifsiz numunelerden elde edilen korozyon akım yoğunluğu değerlerinde lifli numunelere kıyasla artış görülmektedir. Kuruma-kisitlı koşulda bekletilen numunelerde gelişen çatlaklar, ideal-serbest koşulda bekletilen numunelere kıyasla daha büyük korozyon akım yoğunluğu değerlerinin oluşmasına yol açmıştır. Ayrıca, UK ikameli örneklerin toplam çatlak yüzeyi alanı diğer numunelerden çok daha az olduğundan daha düşük korozyon akım yoğunluğu değerleri elde edilmiştir. Bu durum, büzülme çatlaklarının donatı korozyonundaki kuvvetli etkisini işaret etmektedir.

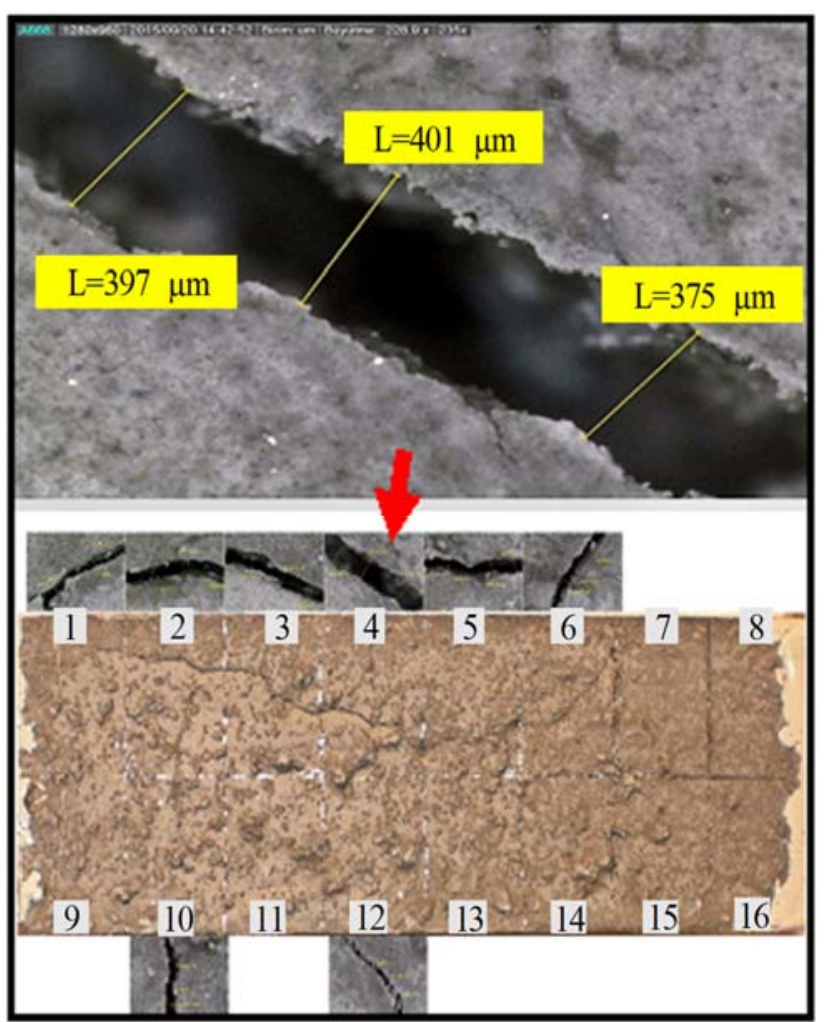

Şekil 16. YFC50-F0 karışımının en geniş çatlak açıklığı ve numune üzerindeki yeri

(The largest crack witdh of YFC50-F0 mixture and its location) 


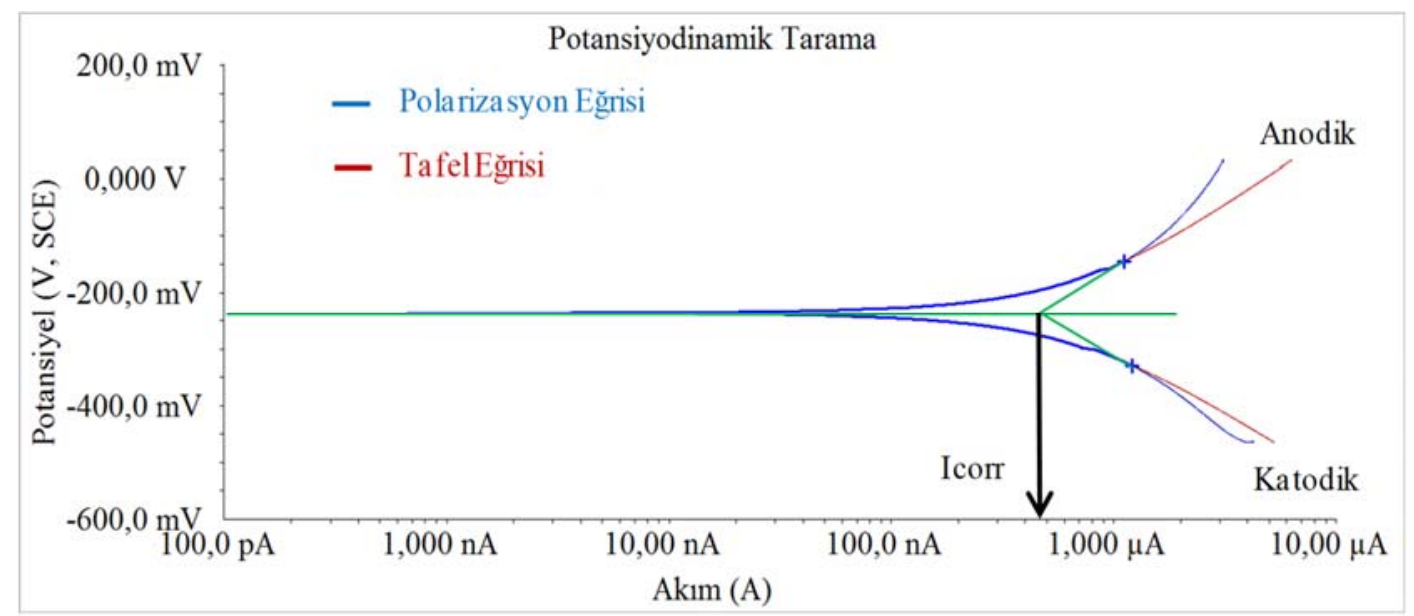

Şekil 17. Betonarme numunelerde polarizasyon eğrisi ve Tafel analizi (Polarization curves and Tafel analysis of reinforced concrete specimens)

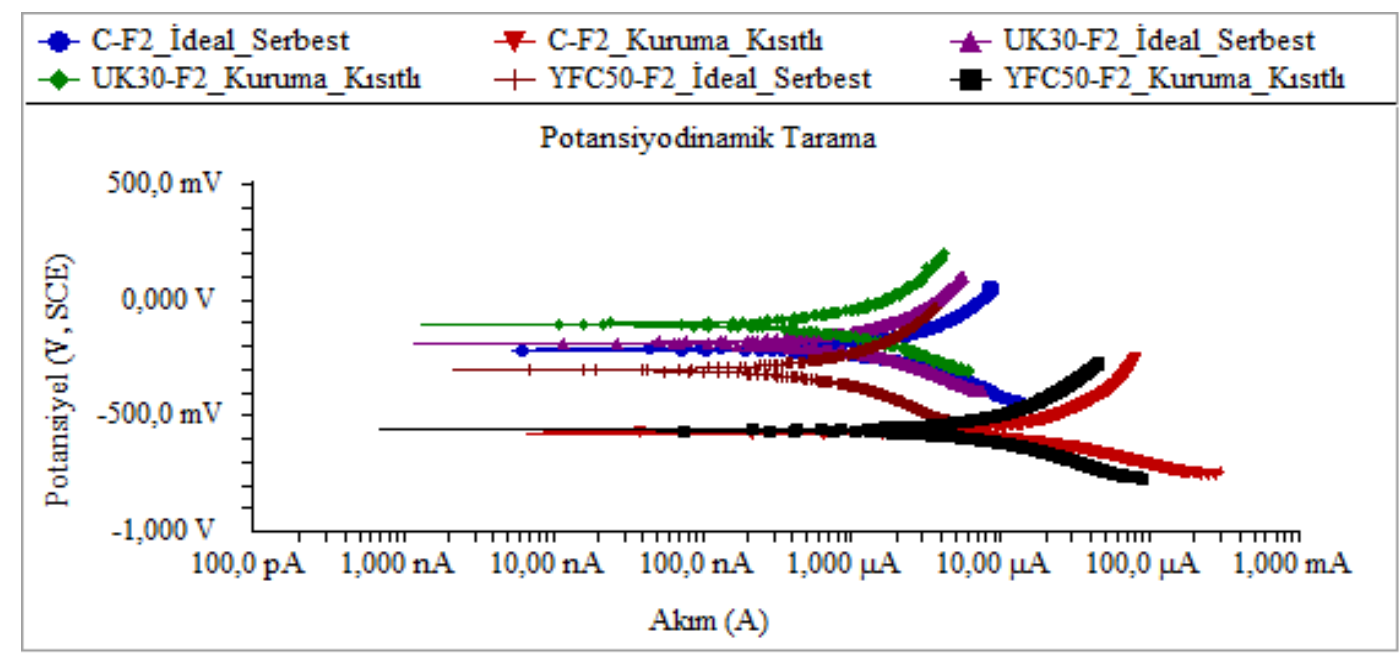

Şekil 18. İdeal-serbest veya kuruma-kısıtlı koşullarında tutulan lifli örneklerin potansiyodinamik tarama eğrileri (Potantiodynamic scan diagrams of the fiber reinforced specimens which were kept under ideal-free or drying-restricted conditions)

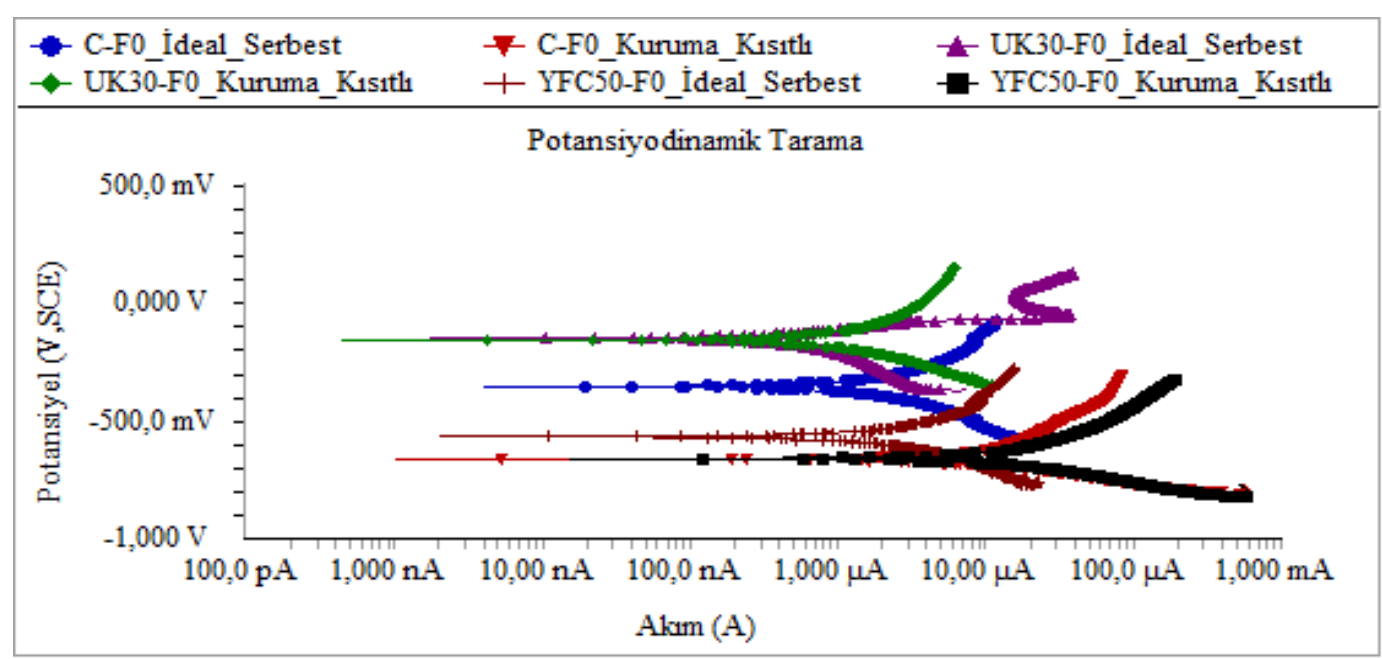

Şekil 19. İdeal-serbest veya kuruma-kısıtlı koşullarında tutulan lifsiz örneklerin potansiyodinamik tarama eğrileri (Potantiodynamic scan diagrams of the fiberless specimens which were kept under ideal-free or drying-restricted conditions) 
Şekil 20'de ilk 24 saat kalıp içerisinde ideal-serbest ve kuruma-kısıtlı koşullarında bekletilmiş numunelerin açık devre potansiyeli değerleri sunulmaktadır. ASTM C876'ya göre $-270 \mathrm{mV}$ potansiyel değeri aktif korozyon gelişimi açısından niteleyici bir sınır olarak kabul edilmektedir. Uçucu kül içeren örneklerde potansiyel değerlerine bakıldığında genel olarak bu limitin altında kaldığ söylenebilir. Açık devre potansiyeli değerleri, karışımların erken yaş büzülme miktarları ve kısıtlı halde çatlak gelişimleri ile paralellik arz etmektedir. Puzolan ikameli karışımlar arasında YFC ikameli karışımın erken yaş büzülmesi ve çatlak gelişimi fazla olduğundan korozyon gelişimi de UK ikameli karışıma oranla daha fazladır.

Şekil 21'de ilk 24 saat kalıp içerisinde ideal koşul ve kuruma koşullarında serbest ve kısıtlı halde bekletilmiş numunelerin korozyon akım yoğunluğu ( $\mathrm{I}_{\text {corr }}$ ) değerleri sunulmaktadır. Numunelerin 28 gün laboratuvar koşullarına tabi tutulduktan sonra yapılan korozyon deneyi sonuçları incelendiğinde çatlak miktarı azaldıkça korozyon akım yoğunluğu da azalmaktadır. Ancak çok geçirimsiz bir malzeme olan UYPB karışımlarında $10 \mathrm{~mm}$ paspayı altında yapılan ölçümde gelişen çatlaklara rağmen korozyon akım yoğunlukları düşük mertebede kalmıştır. UK içeren lifli ve lifsiz karışımda ise korozyon akım yoğunluğu ihmal edilebilir mertebededir [24].

Hızlandırılmış korozyon deneylerinden elde edilen potansiyostatik tarama eğrileri lifli ve lifsiz numuneler için sırasıyla Şekil 22 ve 23 'te logaritmik ölçekte verilmiştir. Bu yöntem hızlandırılmış/zorlanmış bir korozyon deneyi olup yöntemden elde edilen sonuçlar, potansiyodinamik eğriler ile bulunan serbest korozyon akım yoğunluğu değerleri ile paralellik göstermektedir. Eğrilerde akım değerlerinin yüksek olması, daha yüksek korozyon kaybı anlamına gelmektedir. Düşük su/bağlayıcı oranına sahip UYPB karışımları ile üretilen betonarme örnekler, erken yaş koşullarında çatlarsa durabilite olumsuz etkilenmektedir.

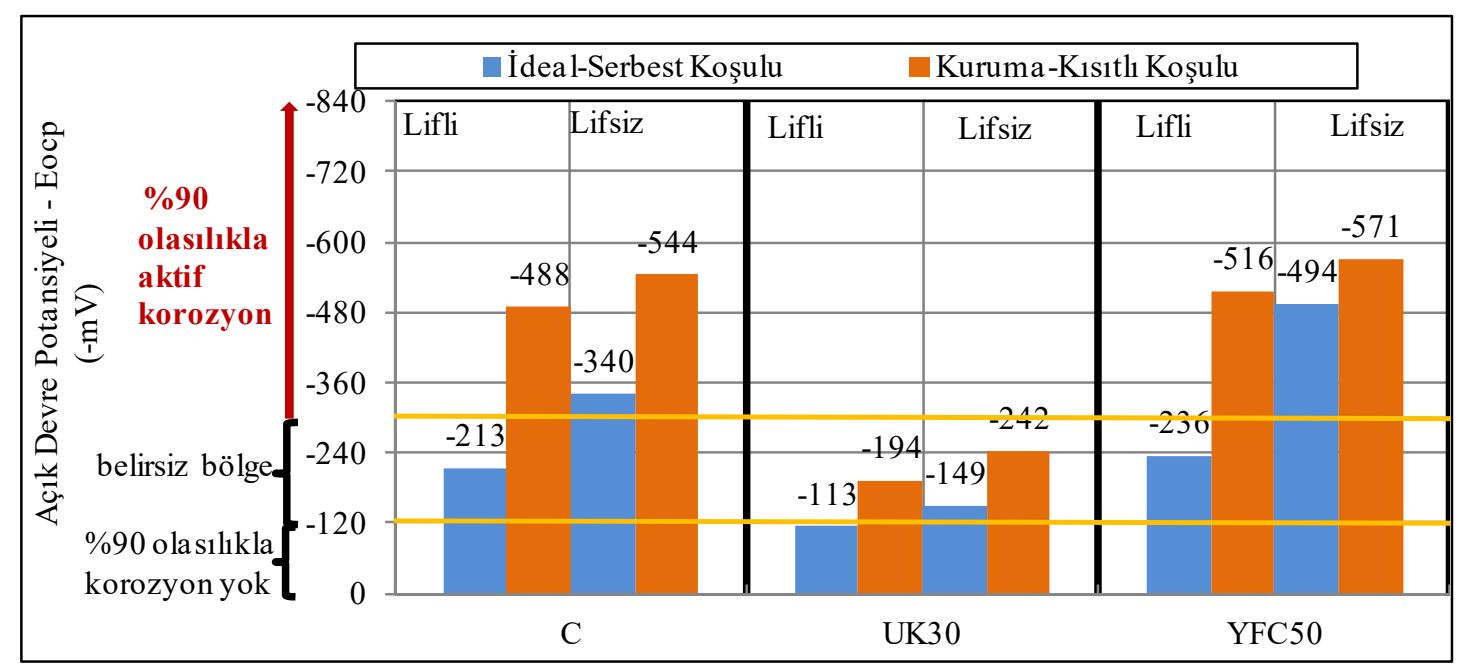

Şekil 20. İdeal-serbest veya kuruma-kısıtlı koşullarında tutulan örneklerin açık devre potansiyeli (Open circuit potantial of the specimens which were kept under ideal-free or drying-restricted conditions)

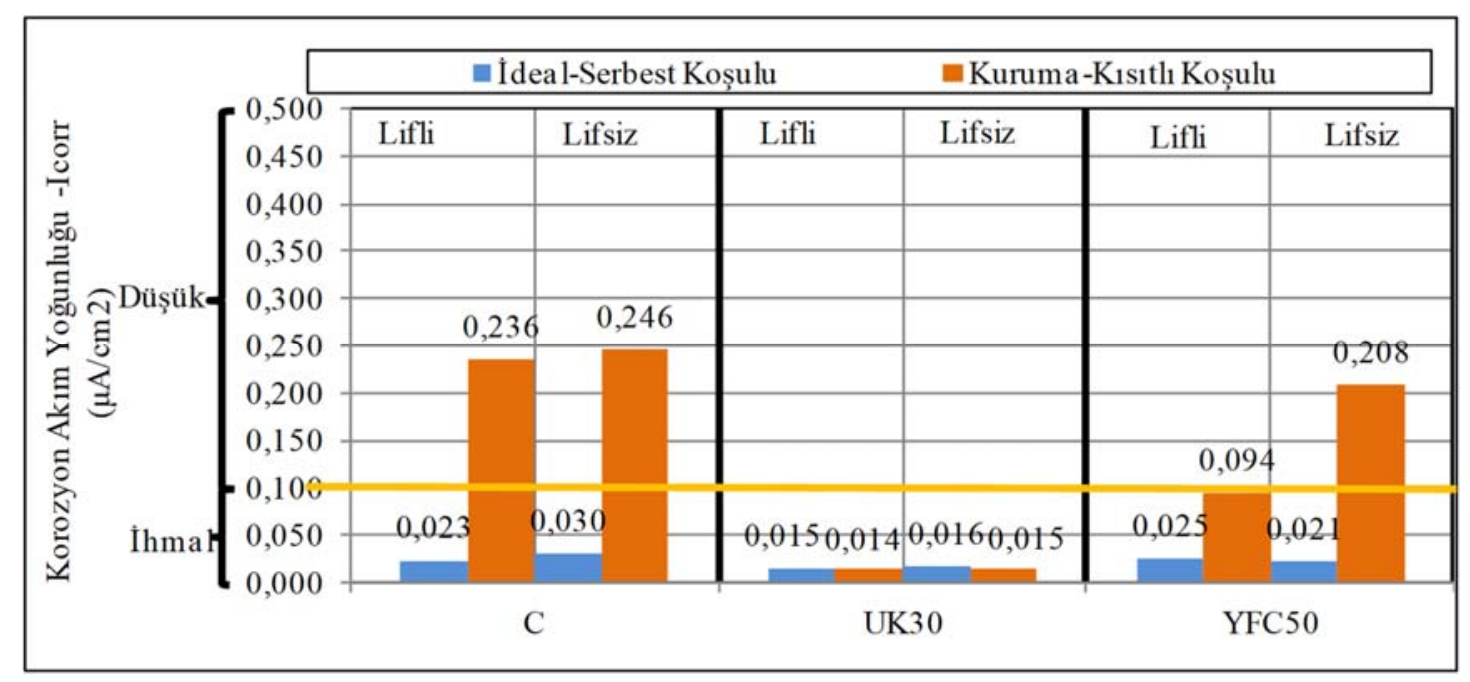

Şekil 21. İdeal-serbest veya kuruma-kısıtlı koşullarında tutulan örneklerin korozyon akım yoğunluğu (Corrosion current density of the specimens which were kept under ideal-free or drying-restricted conditions) 


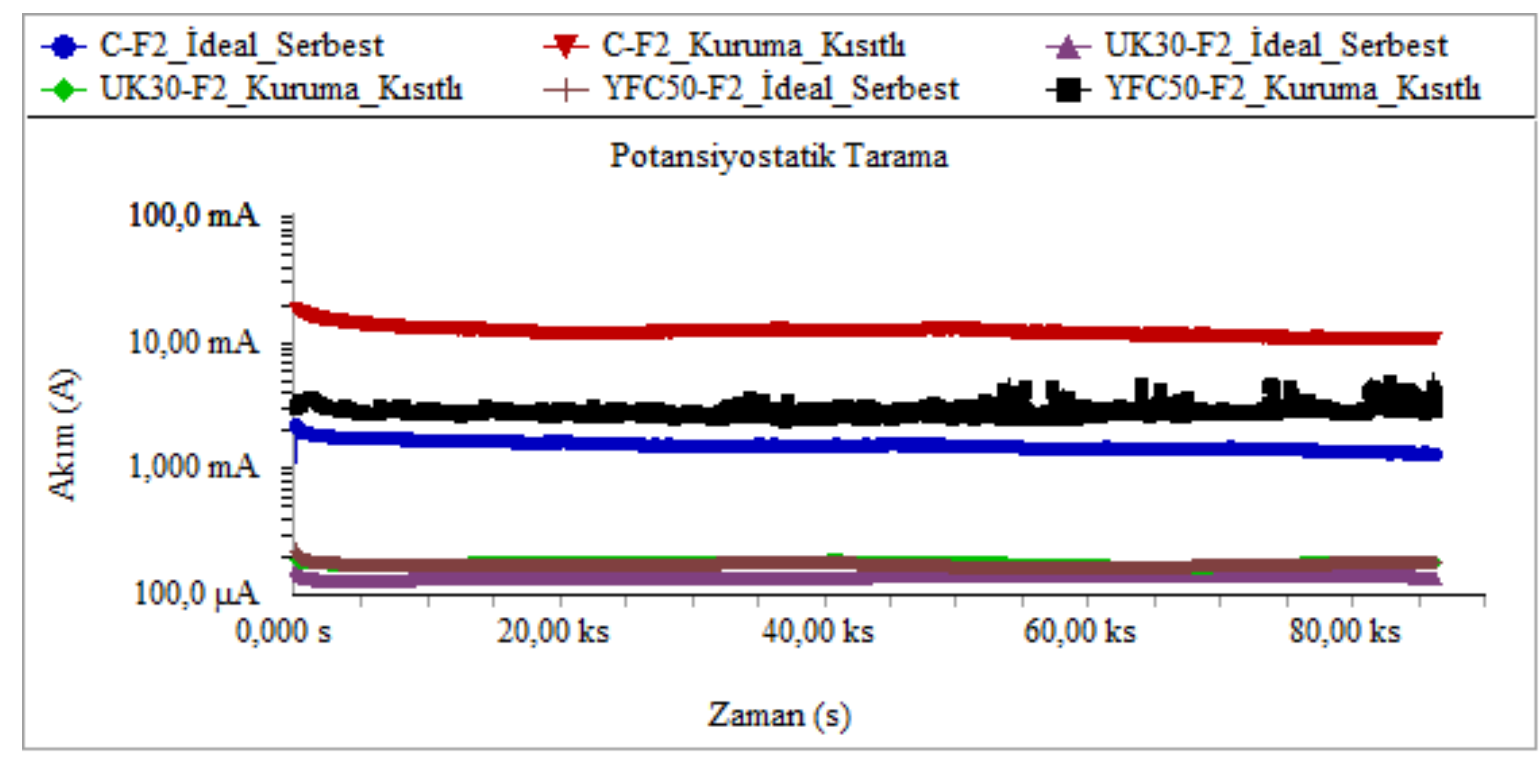

Şekil 22. İdeal-serbest veya kuruma-kısıtlı koşullarında tutulan lifli örneklerin potansiyostatik tarama eğrileri (Potentiostatic scan diagrams of the fiber reinforced specimens which were kept under ideal-free or drying-restricted conditions)

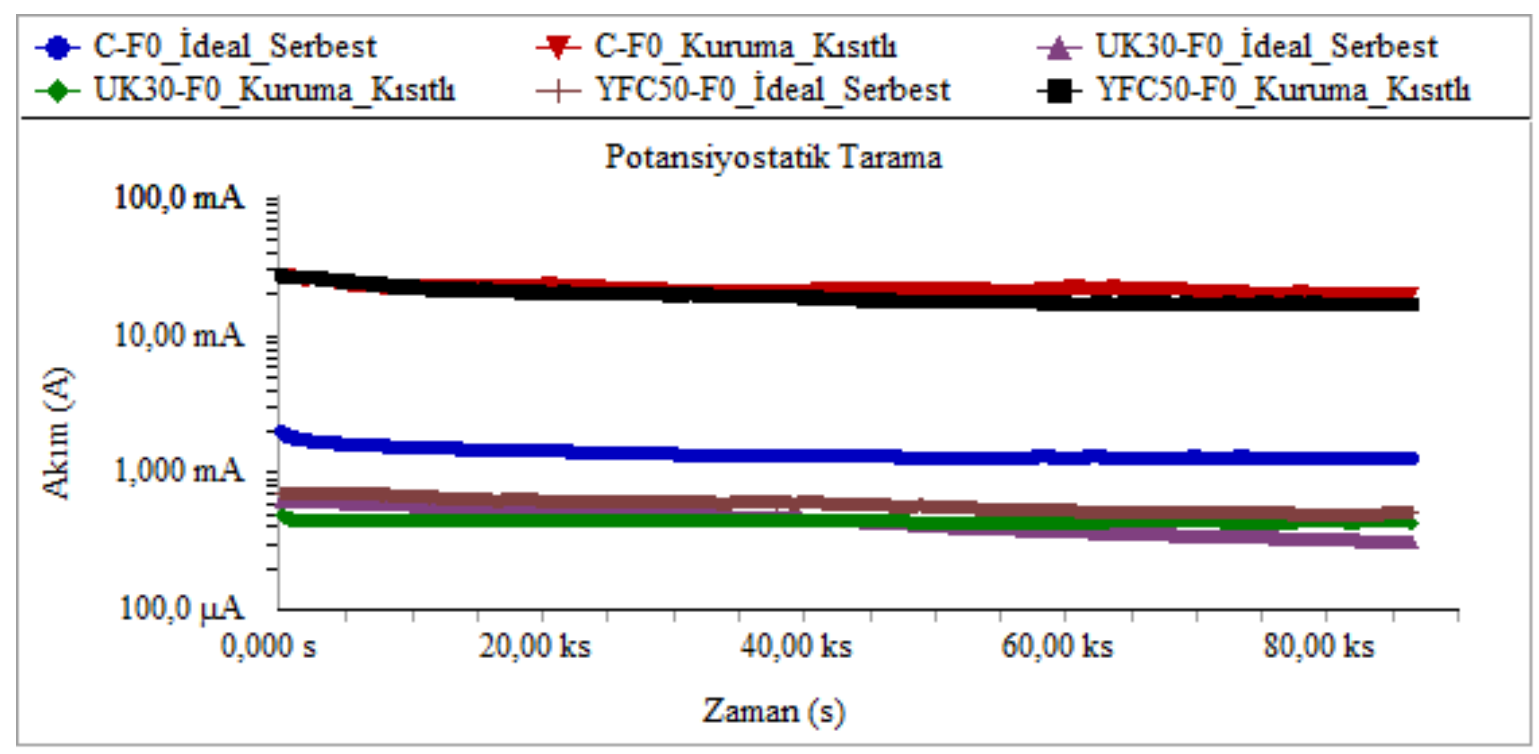

Şekil 23. İdeal-serbest veya kuruma-kısıtlı koşullarında tutulan lifsiz örneklerin potansiyostatik tarama eğrileri (Potentiostatic scan diagrams of the fiberless specimens which were kept under ideal-free or drying-restricted conditions)

Ayrıca çatlak açıklıklarının artışı korozyon gelişimini olumsuz yönde etkilemektedir. Şekil 24 'te kuruma ortamında kısitlı halde bekletilen lif takviyeli numuneler arasinda en geniş çatlağa sahip olanların hızlandırılmış korozyon deneyi öncesi ve sonrası görünümleri sunulmaktadır.

Şekil 24'te belirtilen 0, 1, 2 ve 3 kodlamaları, Şekil 13'te tarif edilen prizmatik numune yüzeylerini belirtmektedir. Çatlak yüzey alanı fazla olan kontrol karışımı ve YFC ikameli karışımda korozyon ürünlerinin beton çatlaklarından yüzeye doğru sızdığı görülmektedir. UK ikameli karışımla üretilen betonarme örneklerde ise bu durum gözlenmemiştir. Şekil 25 'te kuruma ortamında kisitli halde bekletilen lifsiz numuneler arasında en geniş çatlağa sahip olanların hızlandırılmış korozyon deneyi öncesi ve sonrası halleri sunulmaktadır. Çatlaklardan sızan korozyon ürünlerinin miktarı lifsiz numunelerde daha yüksektir. Görsel sonuç elektrokimyasal veriler ile uyumlu olup, C-F0 ve YFC50-F0 betonuna gömülü donatılarda daha fazla oranda korozyon geliştiği görülmektedir.

Hızlandırılmış korozyon deneyi sonrasında numunelerin içinden çıkarılan donatılarda gözlemsel incelemeler yapılmıştır. Deney sonrasında kısıtlanmış lifli ve lifsiz UYPB karışımları içerisinden çıkarılan donatılar sırasıyla Şekil 26 ve Şekil 27'de yer almaktadır. Donatı yüzeyindeki korozyon ürünlerinin miktarı ile karışımların çatlak açıklıkları arasında paralellik görülmektedir. 


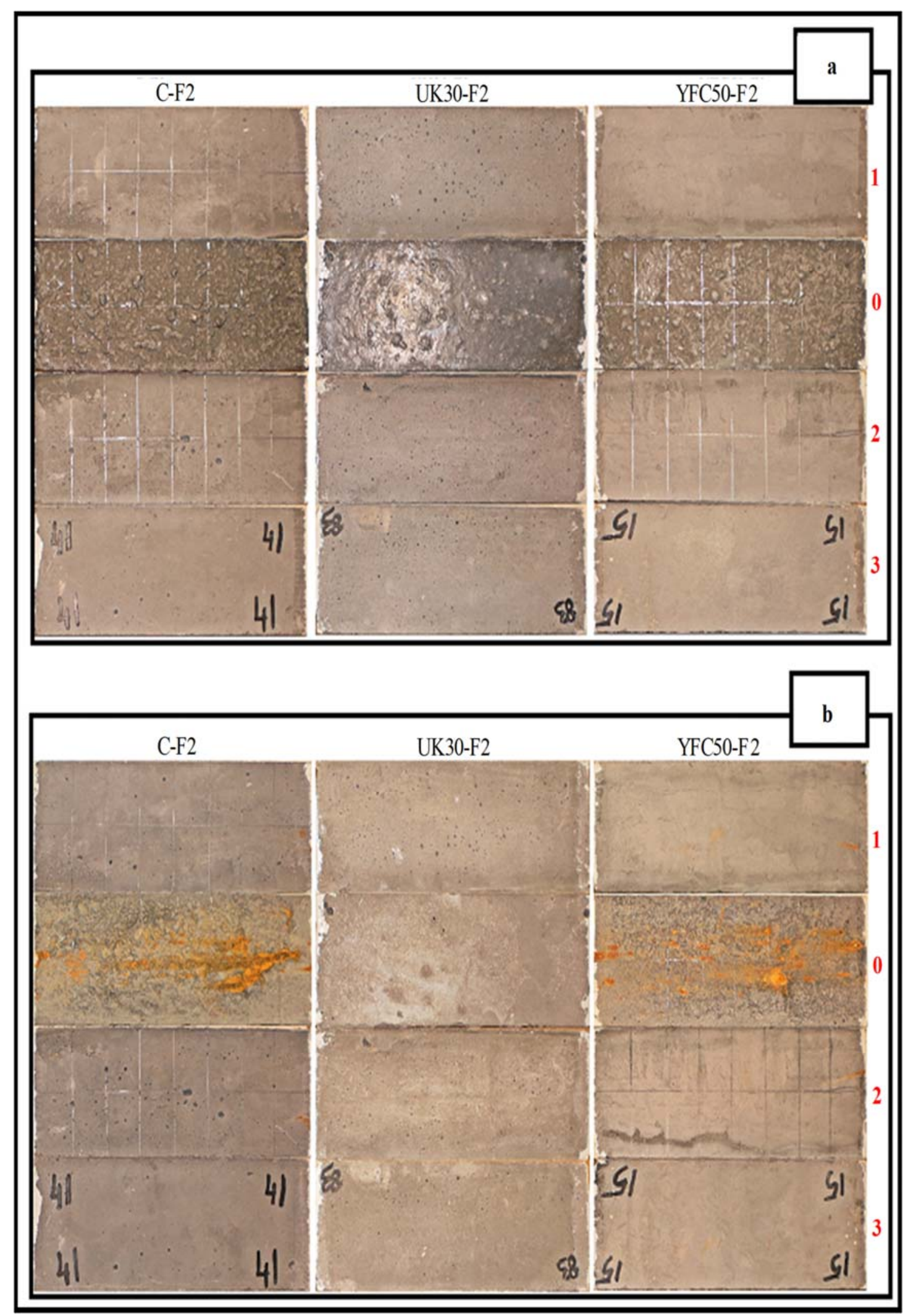

Şekil 24. Lifli numunelerin korozyon deneyinden önceki a) ve sonraki b) görünümü (Appearance of the fiber reinforced specimens before (a) and after (b) corrosion test) 
Erten ve ark. / Journal of the Faculty of Engineering and Architecture of Gazi University 32:4 (2017) 1347-1364

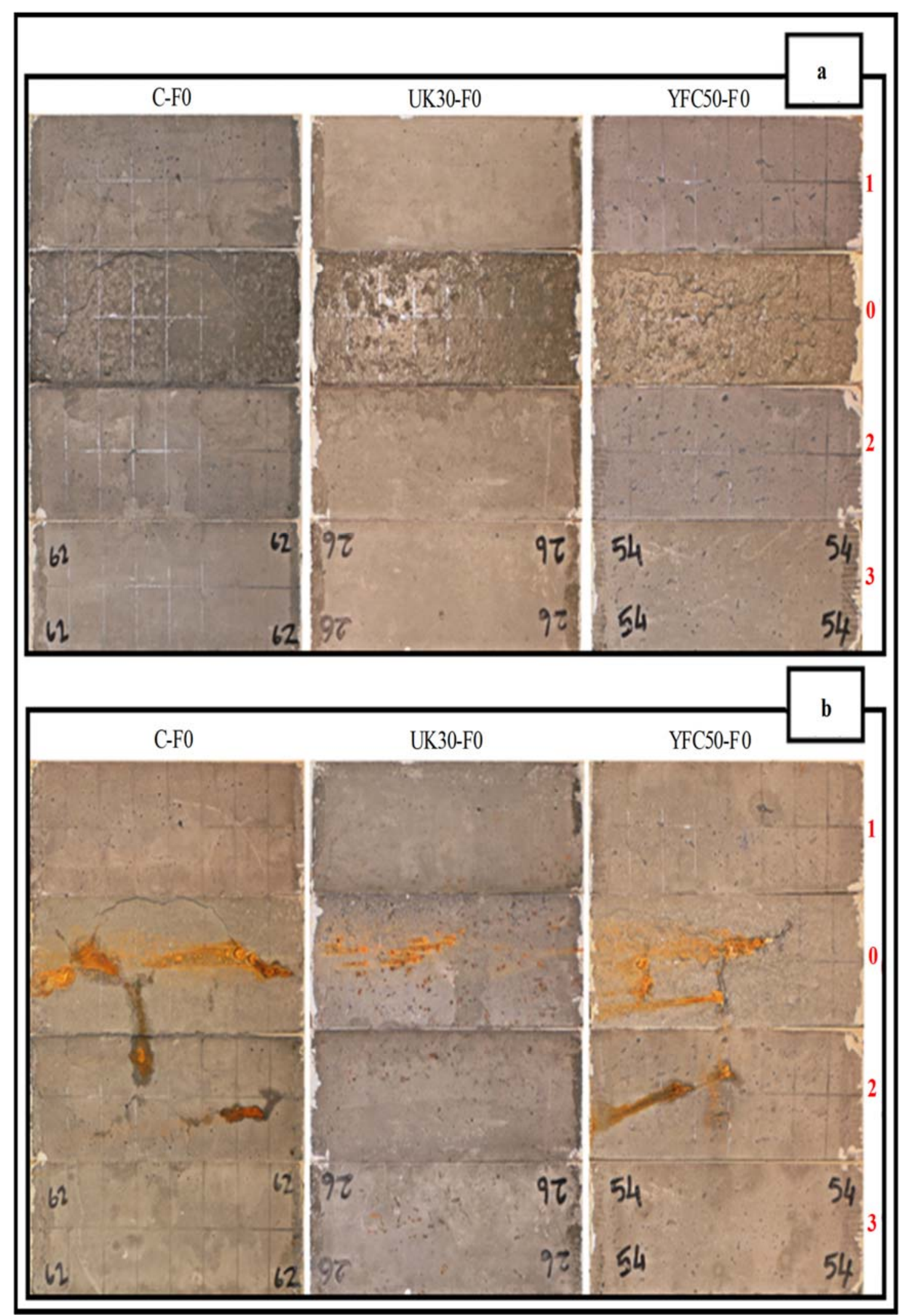

Şekil 25. Lifsiz numunelerin korozyon deneyinden önceki a) ve sonraki b) görünümü (Appearance of the fiberless specimens before (a) and after (b) corrosion test) 


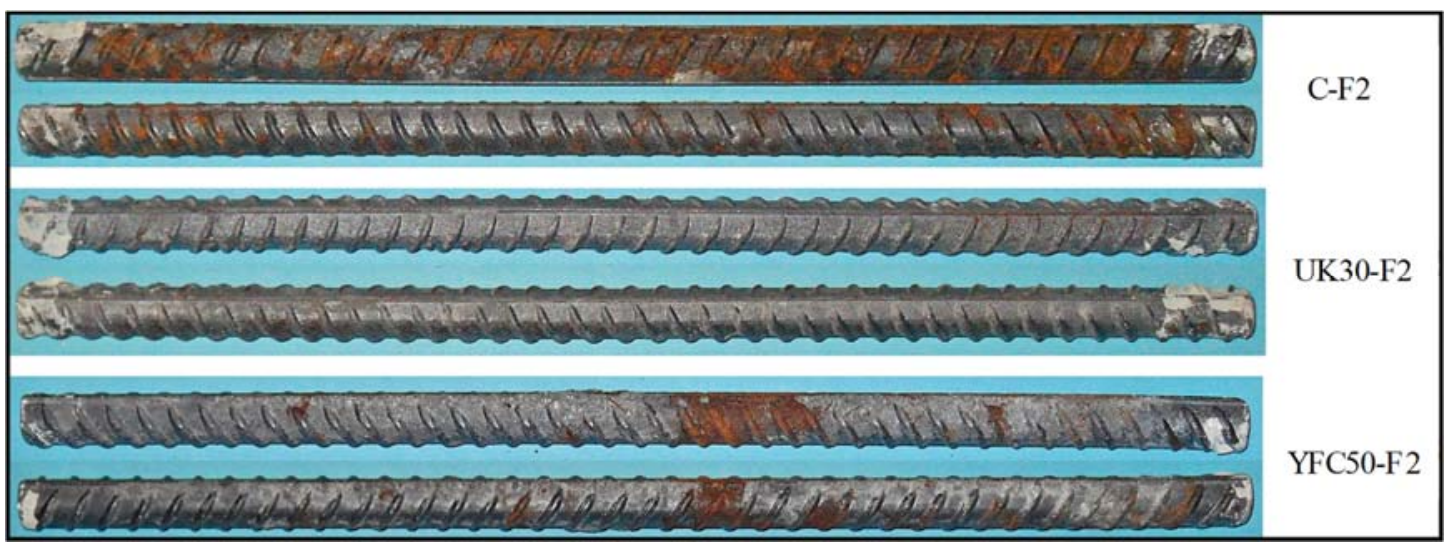

Şekil 26. Kuruma-kısıtlı koşuluna maruz kalan lifli örneklere gömülü donatıların korozyon deneyi sonrası yüzey görünümleri

(The surface appearances of the rebars embedded in fiber reinforced specimens exposed to drying-restricted condition after corrosion test)

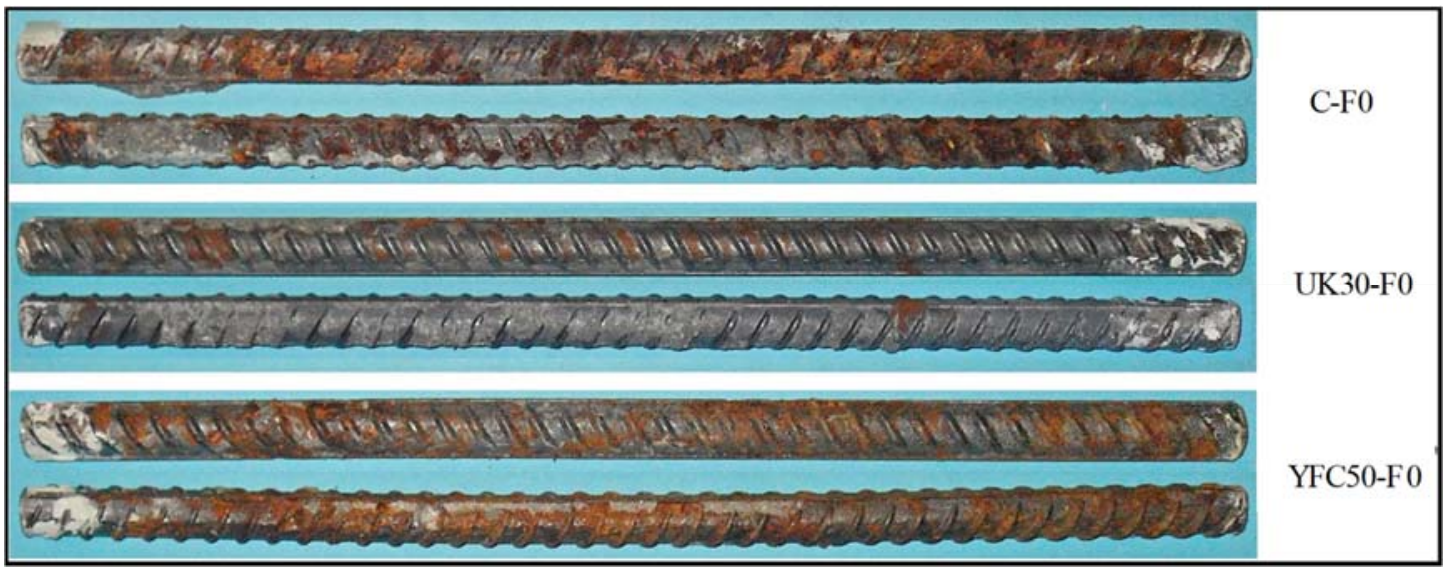

Şekil 27. Kuruma-kısıtlı koşuluna maruz kalan lifsiz örneklere gömülü donatıların korozyon deneyi sonrası yüzey görünümleri

(The surface appearances of the rebars embedded in fiberless specimens exposed to drying-restricted condition after corrosion test)

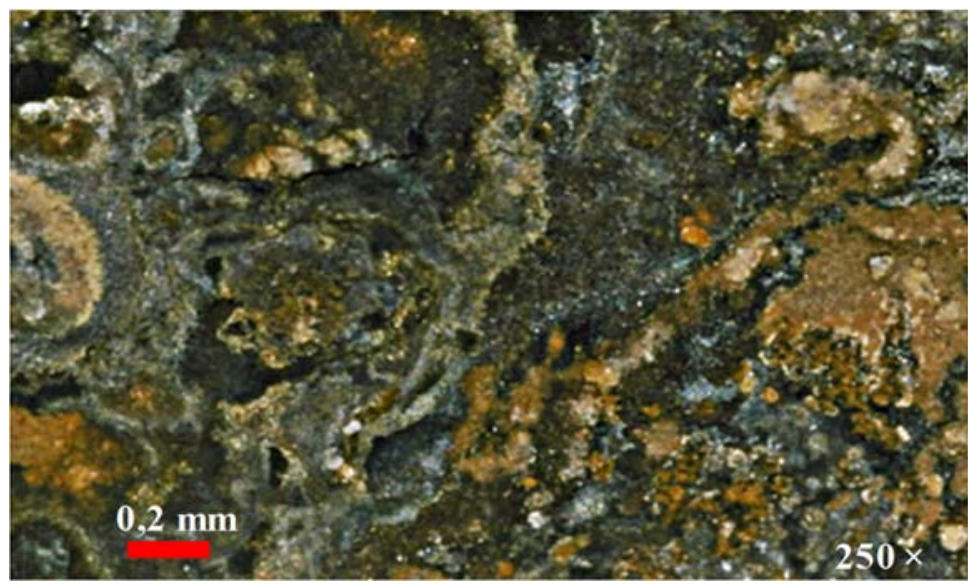

Şekil 28. Korozyon ürünlerinin mikroskop altındaki tipik görünümü (Typical view of corrosion products under the microscope) 


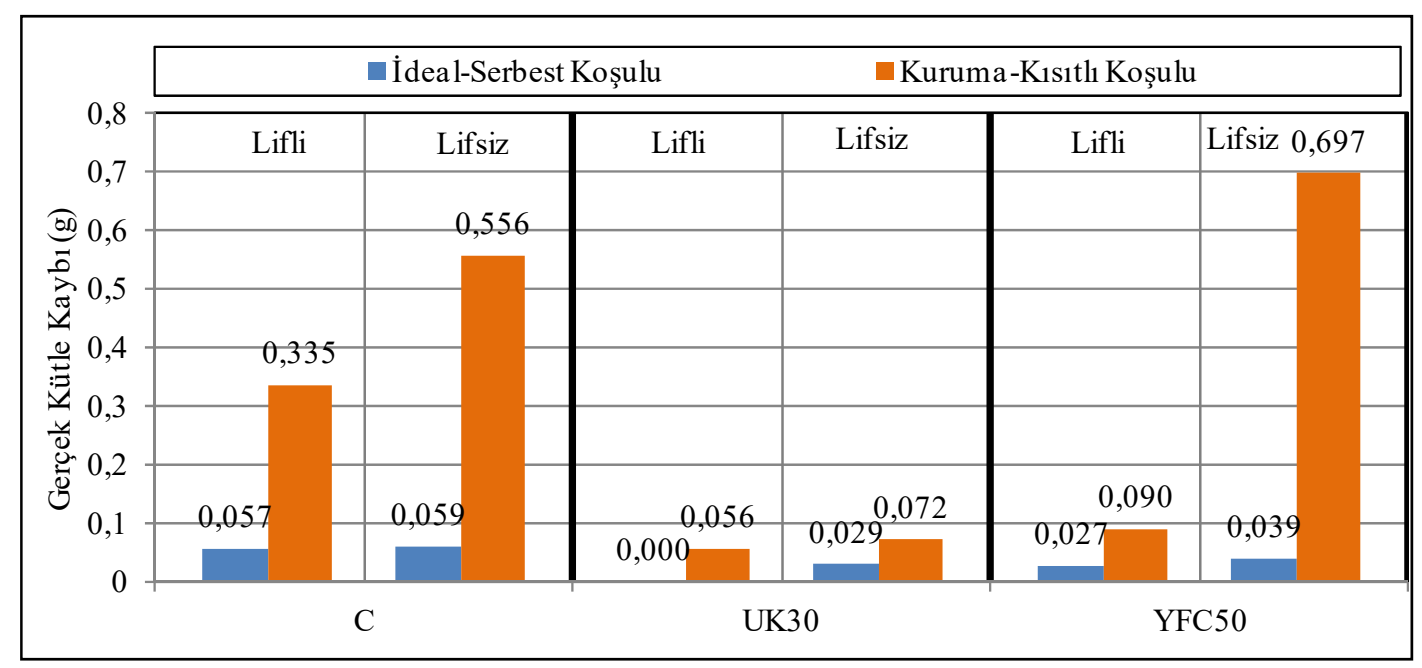

Şekil 29. Donatıların gerçek kütle kayıpları (Actual mass loss of the rebars)

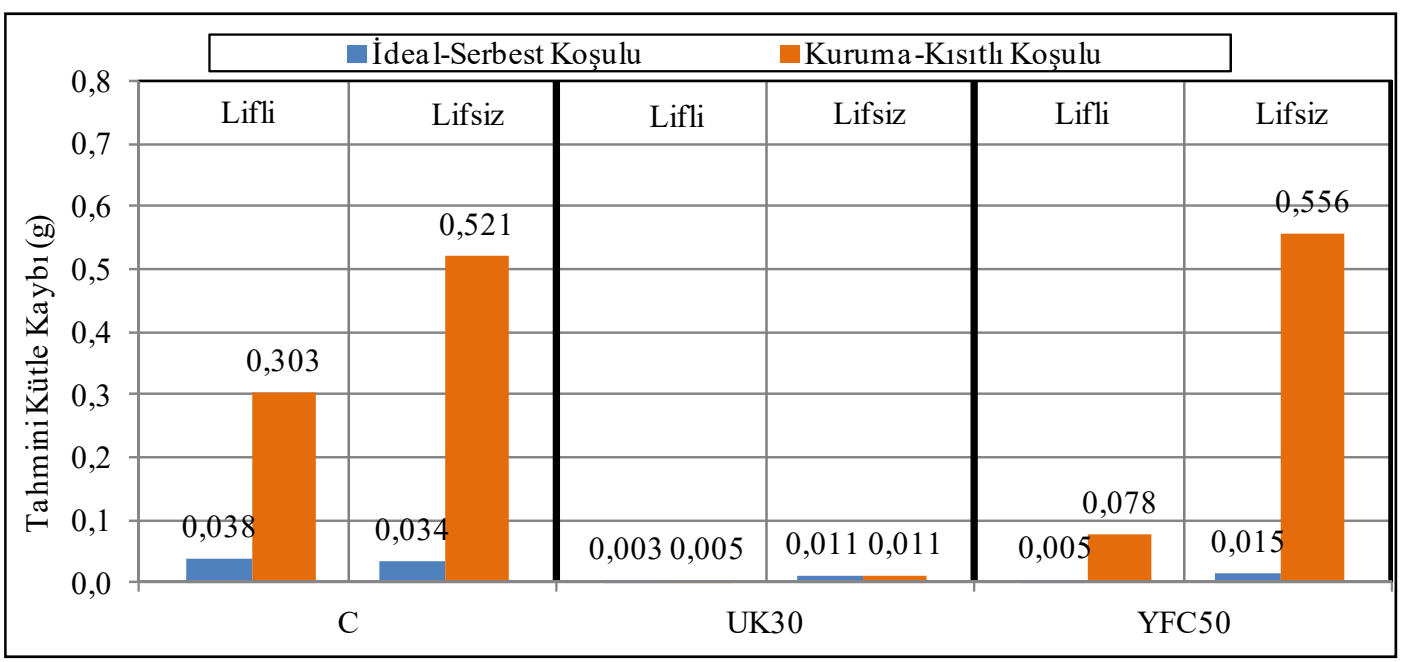

Şekil 30. Donatıların potansiyostatik tarama eğrilerinden hesaplanan tahmini kütle kayıpları (Predicted mass loss of the rebars calculated by potentiostatic scan diagrams)

Liflerin çatlakları önlemesi ile kalıcılığa katkı sağladığı, donatıların lifsiz karışımlara gömülü olması durumunda korozyon hasarının arttı̆gı görülmektedir. Benzer sonuçlar Qi'nin plastik büzülme çatlakları ile ilgili çalışmasında da ortaya konmuştur [25]. Donatı yüzeylerinde gözlenen korozyon ürünlerinin mikroskop altındaki tipik görünümü Şekil 28'de sunulmaktadır.

Hızlandırılmış korozyon deneyleri sonrasında numunelerden çıkartılan çelik donatıların temizlenmesiyle elde edilen gerçek kütle kayıpları Şekil 29'da yer almaktadır. Potansiyostatik tarama eğrileri kullanılarak hesaplanan tahmini kütle kayıpları ise Şekil 30 'da sunulmaktadır. Ölçülen gerçek kütle kayıpları ile potansiyostatik tarama eğrilerinden Faraday Kanunu kullanılarak hesaplanan tahmini kütle kayıpları paralellik göstermektedir. Karışım türüne bağlı olarak numunelerdeki çatlak uzunlukları ve açıklıkları azaldıkça donatıdaki kütle kaybı da azalmıştır. Diğer yandan lif kullanımı ile çatlaklı yapı azaldığından korozyon sonucu oluşan kütle kaybı azalmıştır. İdeal koşullarda bekletilen çatlamamış numunelerin donatılarındaki korozyon gelişimi ihmal edilebilir mertebededir. Bu sonuç çatlamamış UYPB'nin geçirimsizlik özelliğini ve donatıyı koruma etkinliğini göstermektedir [26]. Ülkemizde gerçekleşen depremlerde hasar yapıcı nedenlerin başında beton kalitesinin düşüklüğü ve buna bağlı durabilite sorunları gelmektedir [27]. Gelecekte UYPB kullanımının yaygınlaşması, yüksek dayanımı ve donatıyı koruma etkinliği sayesinde can ve mal kayılarını azaltacaktır.

\section{SİMGELER (SYMBOLS)}

$\begin{array}{ll}\text { A } & \text { Donatı yüzey alanı } \\ \text { CR } & \text { Korozyon hızı } \\ \text { E }_{\text {ocp }} & \text { Açık devre potansiyeli } \\ \text { F } & \text { Faraday sabiti } \\ \text { I } & \text { Elektriksel akım }\end{array}$




$\begin{array}{ll}\mathrm{I}_{\text {corr }} & \text { Korozyon akım yoğunluğu } \\ \mathrm{T} & \text { Zaman } \\ \mathrm{W}_{\mathrm{m}} & \text { Metalin moleküler ağırlığı } \\ \mathrm{Z} & \text { Değerlik } \\ \Delta \mathrm{W} & \text { Kütle kaybı }\end{array}$

\section{SONUÇLAR (CONCLUSIONS)}

UYPB'nin erken yaşta sergilediği bünyesel büzülme ve kuruma büzülmesi mertebeleri oldukça yüksektir. Kuruma büzülmelerinin kısıtlanması halinde çatlaklar oluşmaktadır. UYPB karışımlarına erken yaşta sağlanacak elverişli bir kür ortamının çatlakları önlemedeki önemi büyüktür. Çelik lif takviyesi ile serbest büzülme miktarları belirgin oranda azaltılamazken kısıtlı durumda oluşan çatlakların yüzey alanı önemli oranda azaltılabilmektedir. Ayrıca UK ikamesinin çatlak yüzey alanlarını sınırlamada etkili olduğu belirlenmiştir. UK ikamesi ve lif takviyesi beraber uygulandığında büzülme çatlakları etkili bir biçimde azaltılabilmektedir. Korozyon deney sonuçları, büzülme kaynaklı çatlak gelişimi ile paralellik göstermektedir. YFC ikamesi sonucu erken yaşta büzülme ve çatlak gelişimi arttığından korozyon gelişimi de artmıştır. 10 mm'lik pas payı tabakasındaki çatlaklara rağmen korozyon akım yoğunlukları düşük mertebede kalmıştır. UK ikamesi durumunda korozyon akım yoğunlukları ihmal edilebilir mertebelerdedir. Hızlandırılmış korozyon deneyleri sonrasında ölçülen gerçek kütle kaybı ile hesaplanan tahmini kütle kayıpları paralel sonuçlar vermiştir. Korozyon hızı yüksek numunelerde korozyon ürünlerinin büzülme çatlaklarından dışarı doğru sızdığı gözlenmiştir. Daha fazla büzülme çatlağı içeren numunelerde donatı yüzeyindeki korozyon ürünlerinin yoğunluğu da fazladır. Erken yaşta, ideal koşullarda kür edilen numunelerde büzülme çatlakları oluşmadığından donatılarda korozyon gelişmemiştir. Geleneksel betona kıyasla daha geçirimsiz bir malzeme olan UYPB'den beklenen donatıyı korozyona karşı koruma etkinliği, büzülme çatlaklarının engellenmesi ile daha da arttırılabilir.

\section{TEŞEKKÜR (ACKNOWLEDGEMENT)}

$\mathrm{Bu}$ çalışma Türkiye Bilimsel ve Teknolojik Araştırma Kurumu'nun (TÜBİTAK) desteklediği 110M691 numaralı araştırma projesinin bir kısmı olup, aynı zamanda ilk yazarın doktora tezinden üretilmiştir. Yazarlar projeyi destekleyen TÜBİTAK'a ve Dokuz Eylül Üniversitesi Fen Bilimleri Enstitüsü'ne teşekkürlerini sunar. Ayrıca, deneysel çalışmaya malzeme desteği sağlayan Pomza Export, BASF, OYAK Denizli Çimento, OYAK Adana Çimento, Bekaert firmalarına da teşekkürlerini sunar.

\section{KAYNAKLAR (REFERENCES)}

1. Soliman A.M., Early-age shrinkage of ultra highperformance concrete: mitigation and compensating mechanisms, Doktora Tezi, Western Ontario Üniversitesi, 2011.
2. Yalçınkaya Ç., Yazıcı H., Effects of ambient temperature and relative humidity on early-age shrinkage of UHPC with high-volume mineral admixtures, Constr. Build. Mater., 144, 252-259, 2017.

3. Meng W., Khayat K., Effects of saturated lightweight sand content on key characteristics of ultra-highperformance concrete, Cem. Concr. Res., 101, 46-54, 2017.

4. Min K.H., Jung H.C., Yang J.M., Yoon Y.S., Shrinkage characteristics of high-strength concrete for large underground space structures, Tunnelling Underground Space Technol., 25 (2), 108-113, 2010.

5. Pease B.J., The role of shrinkage reducing admixtures on shrinkage, stress development and cracking, Yüksek Lisans Tezi, Purdue University, Indiana, 2005.

6. Holt E., Leivo M., Cracking risks associated with early age shrinkage, Cem. Concr. Compos., 26 (5), 521-530, 2004.

7. Fehling D., Thiemicke J., Structural Behaviour, Schmidt M., Fehling E., Glotzbach C., Fröhlich S., Piotrowski S. (Ed.), Ultra-High Performance Concrete and Nanotechnology in Construction (1. bask1), Kassel University Press, Kassel, 477-484, 2012.

8. Banthia N., Gupta R., Plastic shrinkage cracking in cementitious repairs and overlays, Mater. Struct., 42 (5), 567-579, 2009.

9. Mokarem D.W., Weyers R.E., Lane D.S., Development of a shrinkage performance specifications and prediction model analysis for supplemental cementitious material concrete mixtures, Cem. Concr. Res., 35 (5), 918-925, 2005.

10. Akkaya Y., Ouyang C., Shah S.P., Effect of supplementary cementitious materials on shrinkage and crack development in concrete, Cem. Concr. Compos., 29 (2), 117-123, 2007.

11. Khalaf F.M., Wilson J.G., Electrical properties of freshly mixed concrete, J. Mater. Civ. Eng., 11, 242248, 1999.

12. Yiğiter H., Betonarme donatısında klorid korozyonu gelişiminin elektrokimyasal yöntemlerle belirlenmesi. Doktora Tezi, Dokuz Eylül Üniversitesi, Fen Bilimleri Enstitüsü, İzmir, 2008.

13. Balbaşı M., Tosun A., Tamirci M., Ergun M., Enzymatic activity on corrosion potential of steel, Journal of the Faculty of Engineering and Architecture of Gazi University, 29 (2), 253-259, 2014.

14. Yalçınkaya Ç., Yazıcı H., Effect of early-age freezethaw exposure on the mechanical performance of selfcompacting repair mortars, Science and Engineering of Composite Materials, 23 (3), 335-344, 2016.

15. Zivica V., Corrosion of reinforcement induced by environment containing chloride and carbondioxide, Bull. Mater. Sci., 26 (6), 605-608, 2003.

16. Çil İ., Betonarme donatısında elektriksel yöntemlerle korozyon ölçümü, DEÜ Mühendislik Fakültesi Fen ve Mühendislik Dergisi, 8 (1), 59-63, 2006.

17. Yazıcı H., Yalçınkaya Ç., Yüksek performanslı çimento esaslı kompozitlerin boyutsal kararlılığının incelenmesi 
ve boyutsal kararlılığın durabilite özelliklerine etkisinin araştırılması, TÜBITTAK Proje No: 110M691, 2014.

18. Yalçınkaya Ç., Yüksek performanslı çimentolu kompozitlerin erken ve ilerlemiş yaşlarda boyutsal stabilitesinin araştırılması, Doktora Tezi, Dokuz Eylül Üniversitesi, Fen Bilimleri Enstitüsü, İzmir, 2015.

19. Bilecik Şeyh Edebali Üniversitesi. Korozyon. mim.bilecik.edu.tr/Dosya/Arsiv/deney_foyleri/

Korozyon\%20deney.pdf. Erişim tarihi 29 Nisan 2016.

20. Zemajtis J., Modeling the time to corrosion initiation for concretes with mineral admixtures and/or corrosion inhibitors in chloride - laden environments, Doktora Tezi, Virginia Polytechnic Institute and State University, Virginia, 1998.

21. Yüzer N., Betonarme yapılarda korozyon ölçüm yöntemleri ve hasar tespiti, Türkiye Mühendislik Haberleri, 426, 134-138, 2003.

22. Lee K.M., Lee H.K., Lee S.H., Kim G.Y., Autogenous shrinkage of concrete containing granulated blastfurnace slag, Cem. Concr. Res., 36 (7), 1279-1285, 2006.
23. Nawa T., Horita T., Autogenous Shrinkage of HighPerformance Concrete, International workshop on microstructure and durability to predict service life of concrete structures, Sapporo-Japan, 1-10, 2004.

24. Andrade C., Alonso C., Corrosion rate monitoring in the laboratory and on-site, Constr. Build. Mater., 10 (5), 315-328, 1996.

25. Qi C., Quantitative assessment of plastic shrinkage cracking and its impact on the corrosion of steel reinforcement. Doktora Tezi, Purdue Üniversitesi, Indiana, 2003.

26. Otieno M., Beushausen H., Alexander M., Chlorideinduced corrosion of steel in cracked concrete - Part I: Experimental studies under accelerated and natural marine environments, Cem. Concr. Res., 79, 373-385, 2016.

27. Duran B., Tunaboyu O., Avşar Ö., Determination of elasticity modulus of low strength concrete and its effect on the risk assessment results by DSVB, Journal of the Faculty of Engineering and Architecture of Gazi University, 32 (1), 253-264, 2017. 